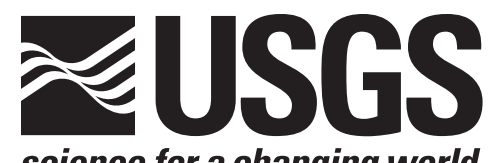

science for a changing world

Prepared in cooperation with the Fallon Paiute-Shoshone Tribe

\title{
Potential for Formation of Disinfection By-Products from Storage of Chlorinated Surface Water in the Basalt Aquifer near Fallon, Nevada
}

Scientific Investigations Report 2005-5142

U.S. Department of the Interior

U.S. Geological Survey 
(Back of Cover) 


\section{Potential for Formation of Disinfection By-Products from Storage of Chlorinated Surface Water in the Basalt Aquifer near Fallon, Nevada}

By Miranda S. Fram, Douglas K. Maurer, and Michael S. Lico

Prepared in cooperation with the Fallon Paiute-Shoshone Tribe

Scientific Investigations Report 2005-5142 


\title{
U.S. Department of the Interior \\ Gale A. Norton, Secretary \\ U.S. Geological Survey \\ P. Patrick Leahy, Acting Director
}

\section{U.S. Geological Survey, Carson City, Nevada, 2005}

For product and ordering information:

World Wide Web: http://www.usgs.gov/pubprod

Telephone: 1-888-ASK-USGS

\author{
World Wide Web: http://www.usgs.gov \\ Telephone: 1-888-ASK-USGS \\ For additional information on Nevada contact: \\ Director \\ USGS, Nevada Water Science Center \\ 333 W. Nye Lane, Room 203 \\ Carson City, NV 89706-0866 \\ email: GS-W-NVpublic-info@usgs.gov \\ http://nevada.usgs.gov
}

For more information on the USGS-the Federal source for science about the Earth, its natural and living resources, natural hazards, and the environment:

Any use of trade, product, or firm names in this publication is for descriptive purposes only and does not imply endorsement by the U.S. Government.

Although this report is in the public domain, it contains copyrighted materials that are noted in the text. Permission to reproduce those items must be secured from the individual copyright owners.

\section{Suggested citation:}

Fram, M.S., Maurer, D.K., and Lico, M.S., 2005, Potential for formation of disinfection by-products from storage of chlorinated surface water in the basalt aquifer near Fallon, Nevada: U.S. Geological Survey Scientific Investigations Report 2005-5142, 23 p., at URL <http://pubs.usgs.gov/sir2005-5142>. 


\section{Contents}

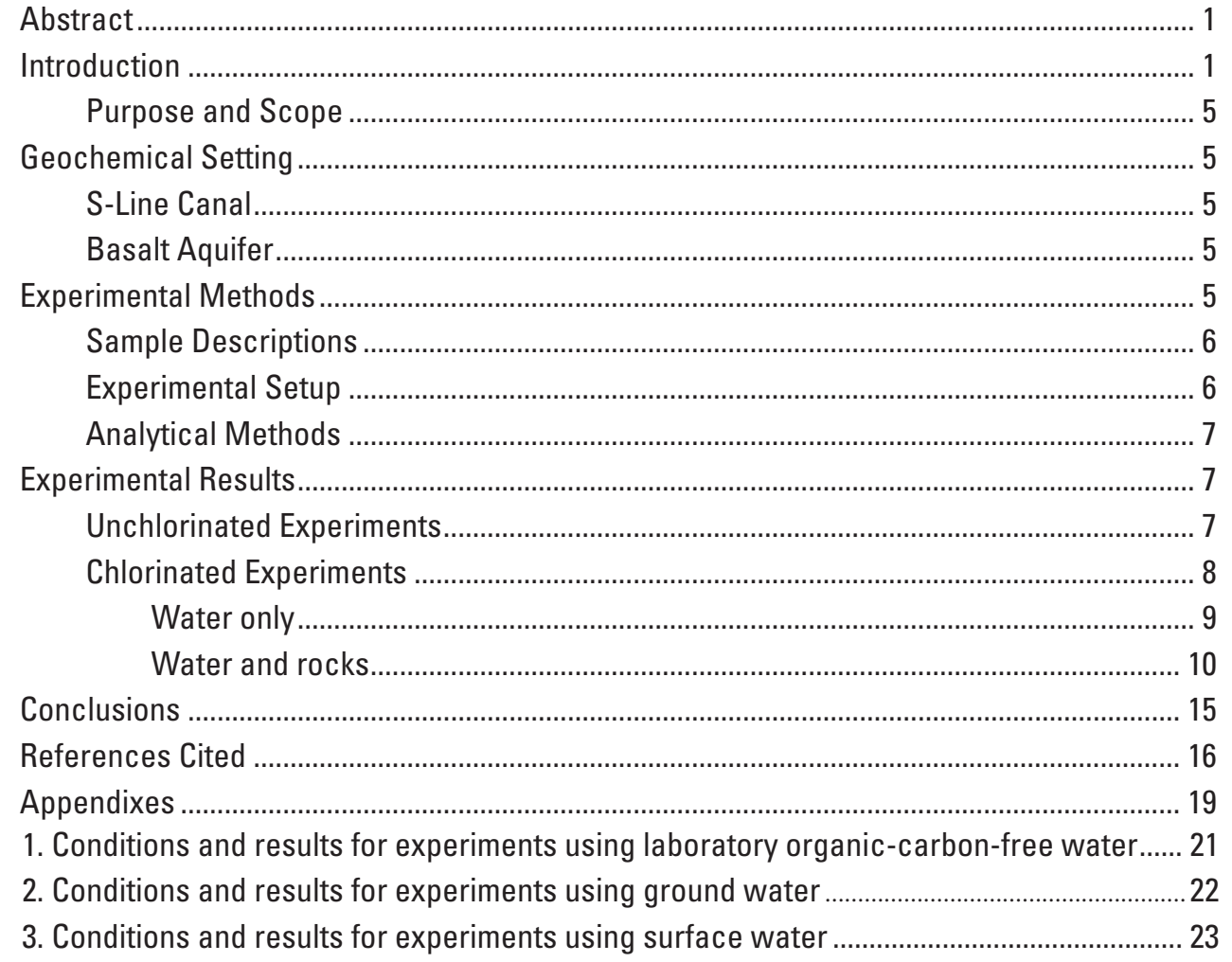

\section{Figures}

1. Map showing location of Carson River Basin and Lahontan Valley.

2. Map showing geographic features of Lahontan Valley and location of basalt aquifer and samples.

3. Graph showing dissolved-organic-carbon (DOC) concentrations in unchlorinated samples of organic-carbon-free laboratory water, ground water from the Fallon basalt aquifer, and surface water from the S-Line Canal in Fallon, NV.

4. Graphs showing dissolved-organic-carbon (DOC) concentrations in samples of organic-carbon-free laboratory water, ground water from the Fallon basalt aquifer, and surface water from the S-Line Canal in Fallon, NV, equilibrated for 20 days with free chlorine at $25^{\circ} \mathrm{C}$ alone and with three different rock samples from the Fallon basalt aquifer.

5. Graphs showing trihalomethane (THM) concentrations in samples of $(A)$ organiccarbon-free laboratory water, $(B)$ ground water from the Fallon basalt aquifer, and $(C)$ surface water from the S-Line Canal in Fallon, NV, equilibrated for 20 days with free chlorine at $25^{\circ} \mathrm{C}$ alone and with three different rock samples from the Fallon basalt aquifer 


\title{
Tables
}

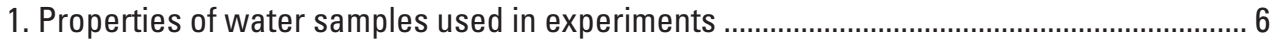

2. Properties of rock samples used in experiments ................................................................ 6

3. Conditions and results for experiments using unchlorinated water ..................................... 8

4. Conditions and results for experiments using chlorinated water only ................................ 9

5. Conditions and results for experiments using rock samples from Rattlesnake Hill and chlorinated water

6. Conditions and results for experiments using rock samples from DB-1 and chlorinated water

7. Conditions and results for experiments using rock samples from DB-4 and chlorinated water

CONVERSION FACTORS, VERTICAL DATUM, AND WATER-QUALITY MEASUREMENTS

\begin{tabular}{|l|c|l|}
\hline Multiply & By & To obtain \\
\hline inch (in.) & 2.54 & centimeter $(\mathrm{cm})$ \\
\hline inch (in.) & 25.4 & millimeter $(\mathrm{mm})$ \\
\hline foot (ft) & 0.3048 & meter $(\mathrm{m})$ \\
\hline mile (mi) & 1.609 & kilometer $(\mathrm{km})$ \\
\hline square mile $\left(\mathrm{mi}^{2}\right)$ & 2.590 & square kilometer $\left(\mathrm{km}^{2}\right)$ \\
\hline
\end{tabular}

Temperature: Degrees Celsius $\left({ }^{\circ} \mathrm{C}\right)$ may be converted to degrees Fahrenheit $\left({ }^{\circ} \mathrm{F}\right)$ as follows: ${ }^{\circ} \mathrm{F}=\left(1.8 x^{\circ} \mathrm{C}\right)+32$. Degrees Fahrenheit $\left({ }^{\circ} \mathrm{F}\right)$ may be converted to degrees Celsius $\left({ }^{\circ} \mathrm{C}\right)$ as follows: ${ }^{\circ} \mathrm{C}=\left({ }^{\circ} \mathrm{F}-32\right) / 1.8$.

Specific conductance is given in microsiemens per centimeter at 25 degrees Celsius $(\mu \mathrm{S} / \mathrm{cm}$ at $\left.25^{\circ} \mathrm{C}\right)$.

\author{
Water-quality measurements used in this report: \\ $\mathrm{cm}$ centimeter \\ ${ }^{\circ} \mathrm{C} \quad$ degrees Celsius \\ g gram \\ $\mathrm{g} / \mathrm{cm}^{3} \quad$ grams per cubic centimeter \\ $\mathrm{L} \quad$ liter \\ mg milligrams \\ $\mathrm{mg} / \mathrm{kg}$ milligrams per kilogram \\ $\mathrm{mg} / \mathrm{L} \quad$ miligrams per liter \\ $\mathrm{mL} \quad$ milliliter \\ $\mathrm{mm}$ millimeter \\ $\mathrm{mM} / \mathrm{M}$ millimoles per mole \\ $\mu \mathrm{M} / \mathrm{L} \quad$ micromole per liter \\ $\mu \mathrm{g} \quad$ microgram \\ $\mu \mathrm{g} / \mathrm{g} \quad$ micrograms per gram \\ $\mu \mathrm{g} / \mathrm{L} \quad$ micrograms per liter \\ $\mu \mathrm{S} / \mathrm{cm}$ microsiemens per centimeter
}




\title{
Potential for Formation of Disinfection By-Products from Storage of Chlorinated Surface Water in the Basalt Aquifer near Fallon, Nevada
}

\author{
By Miranda S. Fram, Douglas K. Maurer, and Michael S. Lico
}

\section{Abstract}

Increased pumpage from a basalt aquifer near Fallon, Nevada, has caused its water levels to decline and has induced changes in the quality of water pumped from the basalt. The aquifer is the sole source of water for municipal supply to the city of Fallon, the Naval Air Station Fallon, and the Fallon Paiute-Shoshone Tribe. These changes may be mitigated by storage of surface water in the basalt for subsequent use. Because chlorination of the surface water may be required for storage, the U.S. Geological Survey, in cooperation with the Fallon Paiute-Shoshone Tribe, made laboratory tests using laboratory organic-carbon-free water, surface-water, groundwater; and basaltic-rock samples to determine the potential for formation of disinfection by-products.

Experiments with water samples only (no rock and no chlorine) indicated no change in dissolved-organic-carbon (DOC) concentrations over a 20-day reaction period; whereas, all experiments using rock, water, and no chlorine indicated an increase in DOC concentrations. The greatest increase in DOC concentrations for all three water samples occurred in experiments with the rock samples from outcrops on Rattlesnake Hill. Experiments with water only and chlorine yielded a total trihalomethane (THM) concentration of $97.4 \mu \mathrm{g} / \mathrm{L}$ for the ground-water sample and $347 \mu \mathrm{g} / \mathrm{L}$ for the surface-water sample.

Experiments with mixtures of water, rocks, and chlorine indicated that reactions with the rock consumed chlorine and released significant amounts of organic carbon from the rock, increasing the DOC concentration in the water. The organic carbon in the rocks likely is associated with the secondary clay minerals that line vesicles and fractures in the rocks. THM concentrations were greatest, from 335 to $909 \mu \mathrm{g} / \mathrm{L}$, for surface water equilibrated with rock samples from Rattlesnake Hill. However, the concentration of chlorine required to produce these high THM concentrations ranged from 18 to 84 $\mathrm{mg} / \mathrm{L}$.

The results of the experiments suggest that the amount of organic carbon released from the rocks during successive cycles of recharge, storage, and recovery of chlorinated surface water may be relatively small. The chlorine demand of the rocks is so large that all of the free chlorine in the entire volume of recharged water likely would be consumed by only a very small volume of the aquifer surrounding an injection well, or beneath an infiltration bed. The majority of the volume of the aquifer filled by the stored water likely would never come in contact with free chlorine, and the increases in concentration of DOC observed in these experiments likely would occur in a very small volume of the stored water. For this reason, increases in concentration of THMs for the entire volume of water stored also likely would be considerably less than those measured in these experiments. To test this hypothesis, additional laboratory experiments using varying levels of chlorination, varying lengths of reaction periods, and repeated cycles of chlorination would be useful. A field experiment made at a small scale in an isolated part of the basalt aquifer would aid in the design of an operational system.

\section{Introduction}

A basalt aquifer near Fallon, NV, is the sole source of water for municipal supply to the city of Fallon, the Naval Air Station Fallon, and the Fallon Paiute-Shoshone Tribe. Fallon is on the western side of Lahontan Valley, the name generally applied to the irrigated part of the Carson Desert. The Carson Desert is the terminus for surface-water flow of the Carson River and also receives surface-water flow from the Truckee River through the Truckee Canal (fig. 1). The basalt aquifer is exposed at Rattlesnake Hill, an eroded volcanic cone, about a mile northeast of Fallon and the remainder is buried beneath sediments deposited by the Carson River and ancient Lake Lahontan to depths of $600 \mathrm{ft}$ near its edges (fig. 2; Maurer and Welch, 2001). In three dimensions, the basalt is a mushroom-shaped body of highly permeable volcanic rock. Viewed from above, the lateral extent of the aquifer is oval-shaped, about $4 \mathrm{mi}$ wide and $10 \mathrm{mi}$ long (fig. 2).

Since the early 1970s, increased pumpage from the basalt aquifer has caused water levels to decline and is thought to have induced changes in the quality of water pumped from the 


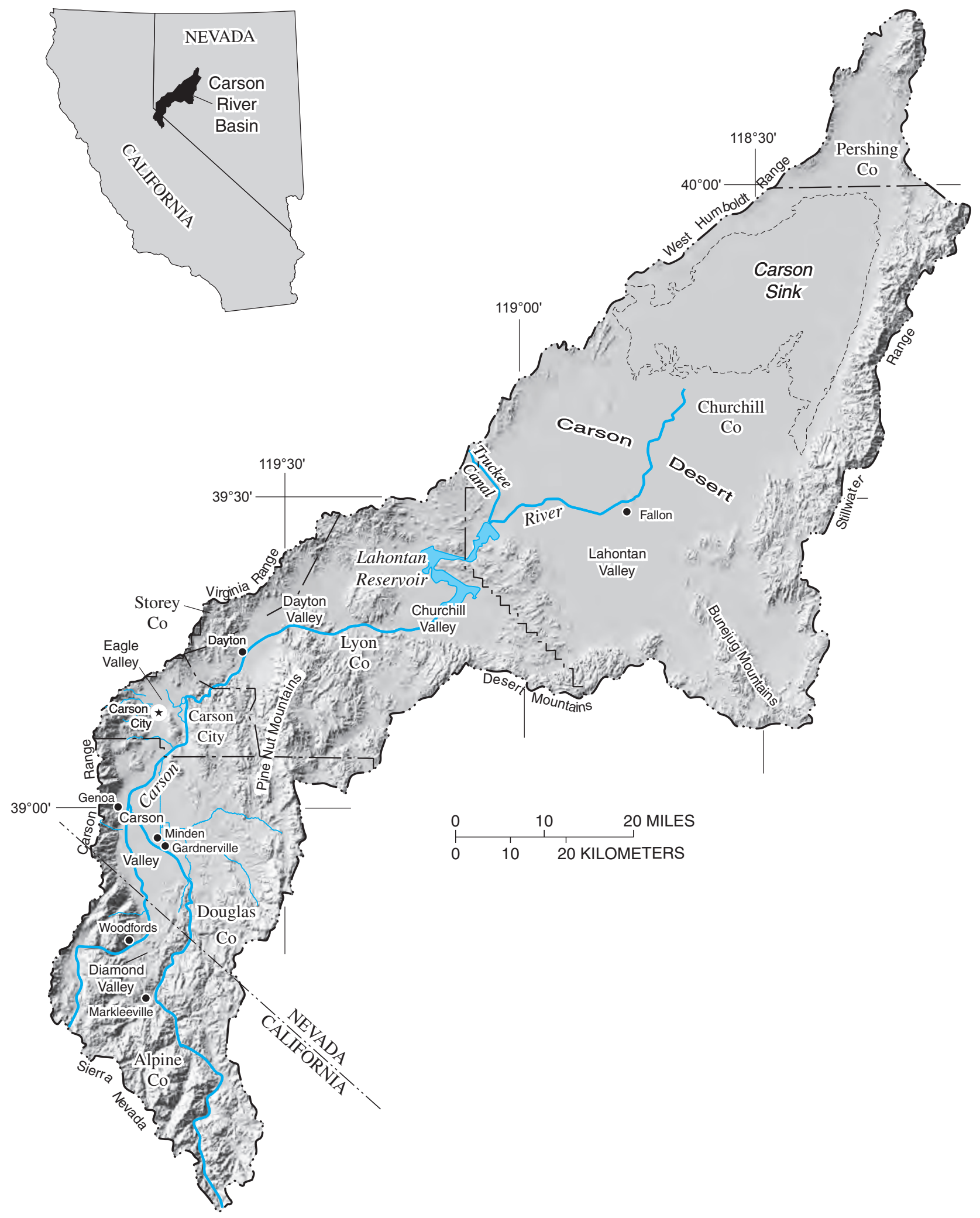

Base from U.S. Geological Survey digital data, 1:100,000-scale, 1979-82 Universal Transverse Mercator projection, zone 11

Figure 1. Location of Carson River Basin and Lahontan Valley. 


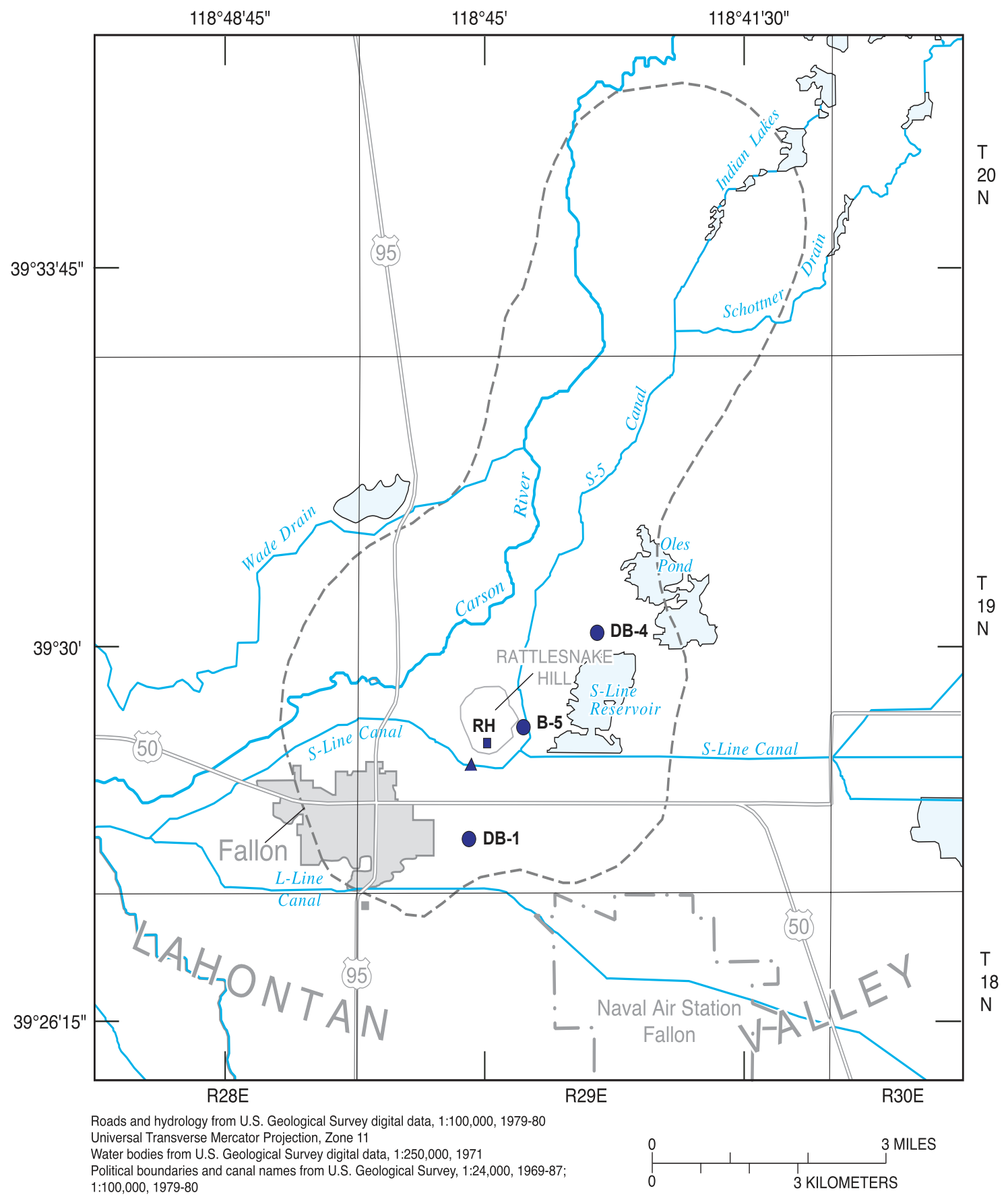

\section{EXPLANATION}

\section{- - - - - Approximate extent of basalt at depth of $\mathbf{6 0 0}$ feet below land surface - From Glancy (1986)}

Well/Test Hole - Location of ground-water or rock sample

- Location of rock sample from surface exposure on Rattlesnake Hill

$\Delta$ Location of surface-water sample from S-Line Canal

Figure 2. Geographic features of Lahontan Valley and location of basalt aquifer and samples. 
basalt. Pumpage increased from about 1,700 acre-ft/yr in the early 1970s to over 3,000 acre-ft/yr in the late 1990s, causing water levels in the aquifer to decline as much as $12 \mathrm{ft}$ over the 20-year period (Maurer and Welch, 2001, p. 30). Maurer and Welch (2001, p. 44-46) reported the concentration of dissolved chloride in water pumped from the basalt by Navy and City of Fallon wells also has increased from the 1970s to the late 1990s. Although chloride concentrations are still below the U.S. Environmental Protection Agency (USEPA) secondary drinking-water standard of $250 \mathrm{mg} / \mathrm{L}$, these changes have caused concern over the continued viability of the basalt aquifer as a source of water as development in the area continues to increase. Concentrations of arsenic in water from the aquifer are about $100 \mu \mathrm{g} / \mathrm{L}$, exceeding the USEPA drinking-water standard of $10 \mu \mathrm{g} / \mathrm{L}$ (U.S. Environmental Protection Agency, 2001), but show no apparent change over time (Maurer and Welch, 2001, p. 10 and 48).

One way to mitigate these changes might be to store surface water in the basalt for subsequent use, by either injecting the water through wells or allowing the water to infiltrate through outcrops of basalt near Rattlesnake Hill. The combined use of ground-water and surface-water resources is often called conjunctive use. Such conjunctive use could decrease the rates of water-level decline and increasing chloride concentrations, and potentially reduce arsenic concentrations near the point of storage. However, because the aquifer is a source of drinking water, disinfection of the surface water may be required for both methods of storage, and therefore, an assessment of the potential for disinfection by-products (DBP) formation during conjunctive use is needed. Drinking water for the City of Fallon and the Naval Air Station Fallon currently is disinfected using chlorination. The same disinfection method likely will be applied to the surface water prior to injection or infiltration into the aquifer.

DBP are formed by reaction between naturally occurring dissolved organic carbon that is present in water, and chlorine that is added for disinfection. Chlorine dissolved in water forms the reactive species hypochlorous acid $(\mathrm{HOCl})$ and hypochlorite ion $\left(\mathrm{OCl}^{-}\right)$. The most abundant $\mathrm{DBP}$ are the trihalomethanes (THMs): $\mathrm{CHCl}_{3}$, chloroform; $\mathrm{CHCl}_{2} \mathrm{Br}$, bromodichloromethane; $\mathrm{CHClBr}_{2}$, dibromochloromethane; and $\mathrm{CHBr}_{3}$, bromoform. THMs are carcinogenic and consumption of water containing elevated concentrations of THMs may increase the risk of miscarriages (U.S. Environmental Protection Agency, 1998, p. 69394). The current maximum contaminant level for the total THM concentration in finished drinking water is 80 $\mu \mathrm{g} / \mathrm{L}$ (U.S. Environmental Protection Agency, 1998) The total concentration of haloacetic acids (HAAs), another class of chlorination by-products, also is regulated, but HAAs appear to biodegrade rapidly in aquifers (Thomas and others, 2000) and therefore likely will be removed from stored water. THMs, particularly the chlorinated species, appear resistant to degradation and thus may persist in the aquifer (Thomas and others, 2000; Fram and others, 2003).

Natural dissolved organic carbon (DOC) is a complex, heterogenous material composed of approximately 40 to 55 percent carbon, with the remainder being oxygen, hydrogen, lesser amounts of nitrogen and sulfur, and trace amounts of other elements. DOC analyses measure the amount of carbon in the DOC in the water sample. All waters contain DOC, but the chemical characteristics of the DOC are not the same in all waters because many environmental sources produce DOC, including plant material, soil organic matter, and algal and microbial activity. The chemical characteristics of DOC in ground waters are generally quite different from those of DOC in surface waters because microbial communities present in most subsurface environments substantially alter any surfacewater DOC that enters the aquifer.

The variation in the chemical characteristics of DOC results in a range of more than a factor of five in the amount of THM formed (normalized to DOC concentration) during chlorination of water samples from different environments (Fujii and others, 1998; Weishaar and others, 2003; Fram and others, 1999). The amount of THM formed divided by the concentration of DOC is defined as the specific THM formation potential (STHMFP). STHMFP has units of millimolar THM per molar DOC (mM/M). STHMFP is broadly correlated with the fraction of the DOC comprised of carbon in aromatic structures, and a number of aromatic structures are known to react with chlorine to form THM (Rook, 1977; Norwood and others, 1980; Reckhow and Singer, 1985; Rebenne and others, 1996). For example:

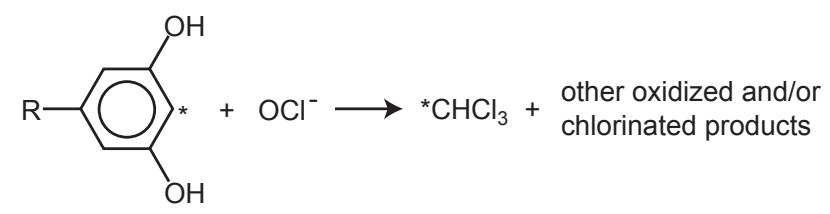

where $*$ is the carbon atom that ends up in the THM, (O) is a benzene aromatic ring,

$\mathrm{R}$ is any organic structure,

$\mathrm{OH}$ is a phenol group,

$\mathrm{CHCl}_{3}$ is chloroform (a THM), and

$\mathrm{OCl}^{-}$is hypochlorite ion.

Note: Reaction is not balanced because many different products are formed in addition to chloroform.

In addition, some nonaromatic structures react with chlorine to form THM (Larson and Rockwell, 1979; Morris and Baum, 1978). For example:

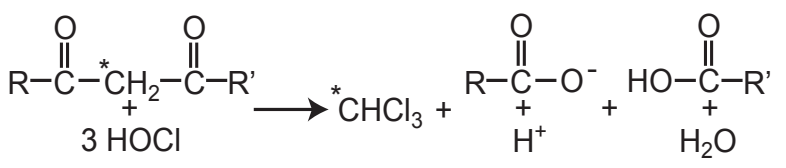

The abundance of structures capable of reacting with chlorine to form THM, such as those represented in reactions 1 and 2, varies with the environmental sources of the DOC in different water samples. In addition to the effects of variable DOC chemical composition, the amount of THM formed during chlorination of a water sample also depends on the concentration of chlorine, concentration of DOC, contact time 
with chlorine, $\mathrm{pH}$, temperature, and the bromide concentration (Reckhow and others, 1990; Crepeau and others, 2004). Therefore, direct experiments are often necessary to make accurate predictions of THM formation from different water samples under different chlorination conditions.

\section{Purpose and Scope}

This report describes laboratory tests and their results from a study that began in September 2002, by the U.S. Geological Survey (USGS), in cooperation with the Fallon Paiute-Shoshone Tribe. The purpose of the study was to determine the potential for formation of DBP, specifically THM, from the storage of chlorinated surface water in the basalt aquifer. For the study, laboratory tests were made using samples of surface water from the S-Line Canal (fig. 2), a likely source for diversion of surface water, ground water from the basalt aquifer, and samples of basaltic rock.

\section{Geochemical Setting}

\section{S-Line Canal}

Previous work by the USGS involved periodic sampling of surface water in the S-Line Canal near Rattlesnake Hill from May 2001 to October 2002 (fig. 2; Welch and others, 2005). Analyses of surface water from the S-Line Canal during that period (Welch and others, 2005) indicated average values of about 8.0 for $\mathrm{pH}$ and concentrations of $190 \mathrm{mg} / \mathrm{L}$ dissolved solids, $4 \mathrm{mg} / \mathrm{L}$ DOC, and $10 \mu \mathrm{g} / \mathrm{L}$ dissolved arsenic. The dominant inorganic ions are sodium, calcium, and bicarbonate. Sulfate concentrations have a narrow range from about 30 to $48 \mathrm{mg} / \mathrm{L}$. Nutrient concentrations generally are low; no samples contained more than $0.45 \mathrm{mg} / \mathrm{L}$ nitrate, or 0.2 $\mathrm{mg} / \mathrm{L}$ phosphate. Trace-element concentrations and radionuclide activities generally were low and did not exceed USEPA drinking-water standards. Arsenic is the notable exception with all but one sample exceeding the $10 \mu \mathrm{g} / \mathrm{L}$ drinking-water standard. Chloride concentrations in the S-Line Canal water are notably lower than the current and historic concentrations in the basalt aquifer. Chloride concentrations were less than 22 $\mathrm{mg} / \mathrm{L}$ in all the samples collected during this study, compared with concentrations in the basalt aquifer that exceed $100 \mathrm{mg} / \mathrm{L}$ (Maurer and Welch, 2001, app. 1) Analyses of bromide concentrations are not available for surface water in the Carson Desert. However, bromide concentrations in samples from the East Fork Carson River near Gardnerville, NV, were less than the method detection limit of $0.01 \mathrm{mg} / \mathrm{L}$ (Bauer and others, 1996, p. 192; Bostic and others, 1997, p. 149). Analyses of surface-water samples for pesticides and other anthropogenic organic compounds indicate very little contamination of S-Line Canal water with these chemicals. Pharmaceuticals and other consumer chemicals including Bisphenol A, caffeine, cholesterol, and DEET were present at very low concentrations, indicating the presence of wastewater in the canal.

\section{Basalt Aquifer}

Water quality in the basalt aquifer generally is uniform over its lateral extent and most likely is a blend of freshwater and water with a higher dissolved-solids content. The observed increase in chloride may be due to more saline water migrating into the basalt aquifer. Water samples from recently drilled wells (Maurer, 2002) indicate that water quality with depth in the basalt is fairly uniform through its entire thickness of about $290 \mathrm{ft}$ near its southern extent, and that ground water in the underlying sedimentary aquifer contains chloride concentrations of almost $2,000 \mathrm{mg} / \mathrm{L}$. Thus, the underlying aquifer could be a source for the increasing chloride concentrations. Water from the basalt aquifer has a $\mathrm{pH}$ from 9.0 to 9.4 , and concentrations of dissolved solids ranged from 500 to $670 \mathrm{mg} / \mathrm{L}$, DOC ranged from 0.4 to $1.1 \mathrm{mg} / \mathrm{L}$, and dissolved arsenic ranged from 95 to $140 \mu \mathrm{g} / \mathrm{L}$ (Maurer and Welch, 2001, p. 10 and 69-72).

The basalt aquifer consists of zones of vesicular, fractured basalt often with abundant coatings on vesicles and fractures, alternating with more massive zones with few vesicles or coatings (Welch and others, 2005). The alternating zones are about $10 \mathrm{ft}$ thick and form a composite body of basalt about $300 \mathrm{ft}$ thick near its southern extent (Maurer, 2002). Because the chemistry of ground water from the basalt is quite similar throughout its thickness, the massive zones likely are fractured allowing water to freely circulate throughout its total thickness. The mineralogy of unweathered basalt is dominated by fine grained plagioclase and augite, as determined by x-ray diffraction. Arsenic concentrations reported for four basalt samples recovered from depths of 399 to $730 \mathrm{ft}$ below land surface ranged from 0.66 to $1.2 \mathrm{mg} / \mathrm{kg}$. The coatings, analyzed by x-ray diffraction, consist of phillipsite, calcite, clay minerals such as nontronite, and iron oxide (Welch and others, 2005; Lico and Seiler, 1994). Phillipsite is a zeolite with cationexchange sites that can affect the quality of water stored in the basalt aquifer.

\section{Experimental Methods}

The potential for enhanced THM formation due to storage of chlorinated surface water in the Fallon basalt aquifer was examined in laboratory experiments. Representative water samples and samples of the Fallon basalt were equilibrated under controlled laboratory conditions with and without added chlorine. DOC, THM, and chlorine concentrations were measured after the equilibration period. 


\section{Sample Descriptions}

Three water samples were used in the experiments: representative surface- and ground-water samples and laboratory organic-carbon-free water. Surface water was collected from the S-Line Canal on July 22, 2003. Because recharged surface water will mix with native ground water during storage in the aquifer, the effect of chlorination on ground water in the aquifer also was examined. Representative water from the Fallon basalt aquifer was pumped from well B-5 on July 22, 2003 (fig. 2). The surface- and ground-water samples were collected in 1-L amber, baked glass bottles and kept chilled until filtration. Samples were filtered by gravity filtration using a $47-\mathrm{mm}$ diameter Teflon filtration apparatus and a 0.3 -micron poresize, baked, glass fiber filter. Filtered samples were stored at $4^{\circ} \mathrm{C}$ until used in experiments. To determine the effect of chlorination on the aquifer material independent of interaction with DOC in the ground- and surface-water samples, experiments also were done using laboratory organic-carbonfree water. This water is produced using a two stage water purification system: Tap water is passed through a Culligan deionizing system and then through a recirculating Picotech UV irradiation and filtration system. DOC concentration, $\mathrm{pH}$, and specific conductance were measured on the three types of water samples prior to the experiments (table 1).

\section{Table 1. Properties of water samples used in experiments}

[See fig. 2 for locations. Abbreviations: USGS, U.S. Geological Survey, Lab., Laboratory; DOC, dissolved organic carbon; SPC, specific conductance; $\mathrm{mg} / \mathrm{L}$, milligrams per liter; $\mu \mathrm{S} / \mathrm{cm}$, microsiemens per centimeter; std units, standard units; na, not applicable. Symbol: <, less than]

\begin{tabular}{cccccc}
\hline $\begin{array}{c}\text { Sample } \\
\text { name }\end{array}$ & $\begin{array}{c}\text { Date } \\
\text { col- } \\
\text { lected }\end{array}$ & $\begin{array}{c}\text { USGS site } \\
\text { identification } \\
\text { number }\end{array}$ & $\begin{array}{c}\text { DOC, } \\
\text { in } \\
\text { mg/L }\end{array}$ & $\begin{array}{c}\mathbf{p H} \text { in std } \\
\text { units }\end{array}$ & $\begin{array}{c}\text { SPC, } \\
\text { in } \\
\mathbf{\mu S / c m}\end{array}$ \\
\hline $\begin{array}{l}\text { S-Line } \\
7 / 22 / 03\end{array}$ & 1031220115 & 2.30 & 8.1 & 274 \\
$\begin{array}{c}\text { Well } \\
\text { B-5 }\end{array}$ & $7 / 22 / 03$ & 392910118442801 & 0.39 & 9.1 & 1,012 \\
$\begin{array}{c}\text { Lab. } \\
\text { water }\end{array}$ & na & none & $<0.02$ & 7.0 & $<1$ \\
\hline
\end{tabular}

Three samples of the Fallon basalt were used in the experiments. The first sample was from a surface outcrop of vesicular basalt on the southern side of Rattlesnake Hill (fig. 2). Hereafter Rattlesnake Hill samples will be referred to as $\mathrm{RH}$. Tests using the outcrop material are considered to represent conditions that may be encountered during recharge by surface infiltration. The other two samples were drill core cuttings from test holes DB-1 and DB-4 (fig. 2). The core sample from DB-1 was taken from the top of the basalt at a depth of $441 \mathrm{ft}$ below land surface. The test hole is about $4,000 \mathrm{ft}$ south of Rattlesnake Hill and the core was taken in a zone of vesicular basalt with abundant coatings on vesicles and fractures. The core sample from DB-4 was taken about $200 \mathrm{ft}$ beneath the top of the basalt at a depth of $536 \mathrm{ft}$ below land surface.
The test hole is about 5,000 ft northeast of Rattlesnake Hill and the core also was taken in a vesicular zone with abundant coatings. Tests using core material are considered to represent conditions that may be encountered during recharge by well injection. All rock samples were broken into pieces $1.5 \mathrm{~cm}$ or less in diameter and stored frozen until used in experiments. Standard thin sections were made for petrographic analysis, and a representative aliquot of each rock sample was analyzed for total- and organic-carbon concentrations (table 2).

Table 2. Properties of rock samples used in experiments

\begin{tabular}{lccc}
\hline \multirow{2}{*}{ Sample name } & $\begin{array}{c}\text { Sample depth, } \\
\text { in feet }\end{array}$ & Total carbon' & $\begin{array}{c}\text { Organic } \\
\text { carbon }^{1}\end{array}$ \\
\cline { 3 - 4 } & Outcrop & 1,000 & 210 \\
\hline $\mathrm{RH}^{2}$ & 441 & 980 & 130 \\
$\mathrm{DB}-1$ & 536 & 100 & 100 \\
$\mathrm{DB}-4$ &
\end{tabular}

${ }^{1}$ Each value represents the mean of three analyses. Standard deviation of the mean is less than 2 micrograms per gram.

${ }^{2}$ Rattlesnake Hill (RH).

Examination of the thin sections of all three basalt samples indicate they contain abundant plagioclase and olivine phenocrysts set in a groundmass composed primarily of plagioclase, clinopyroxene, and oxide minerals. Rounded vesicles, up to $3 \mathrm{~mm}$ in diameter, comprise from about 5 to 25 percent of the volume of rock chips from all three samples. The sample from RH appears to be the most altered of the three samples, because the margins and fractures on olivine phenocrysts are stained with red-brown oxidation minerals, and the vesicles contain coatings petrographically idenitified as clay and zeolite minerals. Olivine phenocrysts in samples DB-1 and DB-4 show almost no oxidation along fractures and margins, and both samples have thinner coatings of secondary minerals in the vesicles than does RH. The groundmasses in RH and DB-1 are holocrystalline, whereas, the groundmass of DB-4 consists of plagioclase microphenocrysts in either cryptocrystalline material or devitrified glass heavily dusted with iron-oxide minerals.

\section{Experimental Setup}

Experiments were done on all three water samples, with and without rock material, and with and without added chlorine. All experiments containing only water were done in quadruplicate in 42-mL, amber, baked glass vials with screw caps containing Teflon-lined septa. Experiments containing water and rock were done in $38-\mathrm{mL}$, amber, baked glass serum vials with crimp caps containing Teflon-lined septa. Duplicate vials were prepared only for one rock:water ratio at one chlorine concentration for each combination of water sample and rock sample due to limited availability of the core-rock samples.

Vials containing only water were used to assess the potential change in DOC concentration during incubation at 
warm temperature. Vials containing water and chlorine were used to determine the THM formation potentials (THMFP) of the three water samples. Free chlorine was added to the vials by syringe in the form of an unbuffered sodium hypochlorite ( $\mathrm{NaOCl}$ ) solution containing $5,000 \mathrm{mg} / \mathrm{L}$ of free chlorine. The amount of chlorine added was estimated to satisfy the chlorine demand of the DOC during the incubation period and to leave a residual free-chlorine concentration of $4 \mathrm{mg} / \mathrm{L}$ at the end of the incubation period.

One vial was prepared with a rock:water ratio, by mass, of approximately 0.4 for each combination of water sample and rock sample and incubated without chlorination. Two to four vials were prepared for each combination of water sample and rock sample with rock:water ratios of approximately 0.14 or 0.88 (total of 44 vials). The vials were spiked with variable amounts of free chlorine. The amount of free chlorine added ranged from 103 to 670 percent of the concentration added to the water samples alone. A range of chlorine concentrations was used, because the chlorine demands of the rocks were not known beforehand. Because these experiments were designed to yield the maximum amount of THM formation, the amount of chlorine added likely was greater than the amount that would be used to chlorinate the surface water for direct use as drinking water.

All vials were sealed with no headspace and held at $25^{\circ} \mathrm{C}$ in the dark for 20 days. The vials were agitated for 5 minutes twice a day to ensure mixing between the water, rock chips, and chlorine. Water and rock masses and the initial concentrations of free chlorine in the water in each vial are listed in appendixes 1, 2, and 3 for experiments with laboratory water, ground water, and surface water, respectively.

At the conclusion of the reaction period, the water in the vials was measured for THM, DOC, and free-chlorine concentrations and $\mathrm{pH}$ value. Aliquots for THM measurement were extracted from the vial by syringe through the septa using a double needle technique. With this method, one needle extracts the sample while another injects air into the vial headspace to prevent THM partitioning. The aliquots were analyzed immediately for THM concentration. A second aliquot was extracted by the same technique and analyzed immediately for free-chlorine concentration. The vials were then opened and the remaining water gravity filtered through a 0.3 micron pore-size baked glass fiber filter using a 47-mm diameter Teflon filtration apparatus. The filtered water was analyzed for $\mathrm{pH}$ and DOC concentration. DOC, THM, residual free-chlorine concentrations, and $\mathrm{pH}$ values for water from each vial are listed in appendixes 1,2, and 3 for experiments with laboratory water, ground water, and surface water, respectively.

\section{Analytical Methods}

DOC concentrations were measured by high-temperature catalytic combustion using a Shimadzu TOC-5000A total organic carbon analyzer (Bird and others, 2003). Free-chlorine concentrations were measured by the Hach DPD spectrophotometric method using a Thermo Spectronics Genesys 20 spectrophotometer (Hach Company, 1997). Values of $\mathrm{pH}$ were measured using an Orion 410A pH meter by standard USGS protocols (Wilde and Radtke, 1998). THM concentrations were measured by purge and trap gas chromatography using a Tekmar 3100 purge and trap unit and a Hewlett-Packard 5890 Series II gas chromatograph with electron capture detection (Crepeau and others, 2004). The samples were manually injected directly into the purge tube of the Tekmar unit immediately after extraction from the vial.

Rock samples analyzed for total and organic carbon were crushed to a fine powder using a clean alumina shatterbox. The shatterbox was cleaned between samples by crushing pure quartz and rinsing thoroughly with laboratory organic-carbonfree water. Concentrations of total and organic carbon were measured using a Perkin-Elmer 2400 series CHNSO analyzer (U.S. Environmental Protection Agency, 1997). Total carbon measurements were made on $100 \mathrm{mg}$ of sample powder packed in tin boats. For organic carbon measurements, $100 \mathrm{mg}$ of sample powder was placed in open silver boats, dampened with organic-carbon-free water, and subjected to vapor-phase acidification with concentrated hydrochloric acid for 6 hours. The boats were then dried and closed for analysis. All samples were measured in triplicate. Detector counts were converted into carbon concentrations using a standard curve constructed with NIST standard 2781, and the standard curve was verified using an acetanilide standard.

\section{Experimental Results}

\section{Unchlorinated Experiments}

Vials containing water only (no rock chips and no chlorine) indicated little or no change in DOC concentrations over the 20-day incubation period; whereas, all vials with rock chips (less than $1.5 \mathrm{~cm}$ diameter) and water, but no chlorine, indicated increases in DOC concentrations (fig. 3). The amount of organic carbon released per mass of rock during the experiment was calculated from the increase on DOC concentration and the mass of rock in each vial. The greatest increase in DOC concentrations for all three water samples occurred with material from the Rattlesnake Hill surface outcrop. Rock samples from RH, and test holes DB-1 and DB-4 released an average for all water types of $5.7 \pm 1.2,1.6 \pm 0.6$, and $1.1 \pm$ $0.2 \mu \mathrm{g}$ organic carbon per gram of rock ( \pm values are 1-standard deviation about the mean), respectively, into the water during the 20-day reaction period (table 3 ). The amount of organic carbon released into the dissolved phase represented less than 3 percent of the organic carbon originally present in the rock samples (table 2).

Because the water sample was collected from the basalt aquifer where it was presumably in contact with rocks similar to those in test holes DB-1 and DB-4, it was expected that 
no increase in DOC concentration would occur in the vials containing ground water and chips from test holes DB-1 or DB-4. However, fresh rock surfaces were generated when the drill core was taken and when the samples were broken into chips to fit in the vials, exposing organic carbon on the fresh surfaces that had not previously been equilibrated with ground water.

Table 3. Conditions and results for experiments using unchlorinated water

[Abbreviations: DOC, dissolved organic carbon; OC, organic carbon; THM, trihalomethane; RH, Rattlesnake Hill; g, grams; mg/L, milligrams per liter; $\mu \mathrm{g} / \mathrm{L}$, micrograms per liter; std units, standard units; na, not analyzed; nd, not detected $(<0.2 \mu \mathrm{g} / \mathrm{L})$; wtr only, water only. Values rounded to three significant figures]

\begin{tabular}{|c|c|c|c|c|c|c|}
\hline $\begin{array}{c}\text { Vial } \\
\text { number }\end{array}$ & $\begin{array}{l}\text { Rock } \\
\text { source }\end{array}$ & $\begin{array}{c}\text { Rock/ } \\
\text { water, } \\
\text { in } \\
\text { mass } \\
\text { ratio }\end{array}$ & $\begin{array}{l}\mathrm{pH} \text {, in } \\
\text { stan- } \\
\text { dard } \\
\text { units }\end{array}$ & $\begin{array}{c}\text { DOC, } \\
\text { in } \\
\mathrm{mg} / \mathrm{L}\end{array}$ & $\begin{array}{c}\text { OC re- } \\
\text { leased/g } \\
\text { of rock, } \\
\text { in } \mu \mathrm{g}\end{array}$ & $\begin{array}{c}\text { Total } \\
\text { THM, } \\
\text { in } \\
\mu \mathrm{g} / \mathrm{L}\end{array}$ \\
\hline \multicolumn{7}{|c|}{ Unchlorinated laboratory organic-carbon-free water } \\
\hline GR03083 & RH & 0.40 & 7.82 & 1.90 & 4.72 & nd \\
\hline GR03086 & DB-1 & 0.37 & 9.69 & 0.88 & 2.32 & nd \\
\hline GR03089 & DB-4 & 0.42 & 9.50 & 0.61 & 1.39 & nd \\
\hline GR03092 & wtr only & 0.00 & na & 0.05 & na & nd \\
\hline GR03093 & wtr only & 0.00 & na & 0.04 & na & na \\
\hline GR03094 & wtr only & 0.00 & na & 0.00 & na & na \\
\hline GR03095 & wtr only & 0.00 & na & 0.00 & na & na \\
\hline \multicolumn{4}{|c|}{ average for water only } & 0.02 & & \\
\hline \multicolumn{7}{|c|}{ Unchlorinated ground water } \\
\hline GR03084 & RH & 0.39 & 7.98 & 2.58 & 5.56 & nd \\
\hline GR03087 & DB-1 & 0.38 & 8.73 & 1.01 & 1.61 & nd \\
\hline GR03090 & DB-4 & 0.42 & 8.70 & 0.77 & 0.90 & nd \\
\hline GR03096 & wtr only & 0.00 & 8.58 & 0.40 & na & nd \\
\hline GR03097 & wtr only & 0.00 & 8.64 & 0.38 & na & na \\
\hline GR03098 & wtr only & 0.00 & 8.67 & 0.36 & na & na \\
\hline GR03099 & wtr only & 0.00 & 8.66 & 0.36 & na & na \\
\hline \multicolumn{4}{|c|}{ average for water only } & 0.38 & & \\
\hline \multicolumn{7}{|c|}{ Unchlorinated surface water } \\
\hline GR03085 & RH & 0.38 & 7.51 & 4.98 & 7.01 & nd \\
\hline GR03088 & DB-1 & 0.37 & 8.39 & 2.67 & 0.99 & nd \\
\hline GR03091 & DB-4 & 0.41 & 8.79 & 2.69 & 0.94 & nd \\
\hline GR03100 & wtr only & 0.00 & 8.19 & 2.30 & na & nd \\
\hline GR03101 & wtr only & 0.00 & 8.14 & 2.29 & na & na \\
\hline GR03102 & wtr only & 0.00 & 8.14 & 2.22 & na & na \\
\hline GR03103 & wtr only & 0.00 & 8.12 & 2.30 & na & na \\
\hline \multicolumn{4}{|c|}{ average for water only } & 2.28 & & \\
\hline
\end{tabular}

\section{Chlorinated Experiments}

THMFP is defined as the amount of THM formed from a water sample under standardized conditions of temperature, $\mathrm{pH}$, contact time with chlorine, DOC concentration, and residual free-chlorine concentration at the end of the incubation period in a laboratory setting. For these experiments, temperature and contact time were held constant at $25^{\circ} \mathrm{C}$ and 20 days, respectively, even though water may be stored in the basalt aquifer for long periods. In contrast, the standard THMFP method of Crepeau and others (2004) specifies a contact time of 7 days and requires buffering of $\mathrm{pH}$ to a value of 8.3 and a residual free-chlorine concentration of $2-4 \mathrm{mg} / \mathrm{L}$. The standard method generally is applied to filtered or unfiltered water samples and not to water-rock mixtures. A pH buffer was not added to the water in the experiments containing rock samples to allow evaluation of changes in $\mathrm{pH}$ from water-rock interactions. As stated previously, the chlorine demand of the rocks was not known beforehand; therefore, it was difficult to control the amount of residual free chlorine after incubation. For these reasons, the THMFP values determined in this study will be reported as THM concentrations that can be compared 
as long as residual free-chlorine concentrations are considered, but are not directly comparable to THMFP values determined for water samples in other studies using the standard method.

\section{Water only}

The average DOC concentration of the chlorinated laboratory water was $0.09 \mathrm{mg} / \mathrm{L}$ and the average total THM was $1.9 \mu \mathrm{g} / \mathrm{L}$ (table 4; vials GR02952-GR02955). This amount is slightly greater than the $1.2 \mu \mathrm{g} / \mathrm{L}$ permitted for maximum THMFP in a full procedural blank for the standard THMFP method (Crepeau and others, 2004). However, as noted previously, the standard THMFP method specifies a contact time of only 7 days, and in the presence of free chlorine, THM formation may continue for several weeks (Reckhow and Singer, 1985; Gallard and von Gunten, 2002; Fram and others, 2003).

The average DOC concentration of the chlorinated ground-water samples was $0.46 \mathrm{mg} / \mathrm{L}$ and the average total THM was $57 \mu \mathrm{g} / \mathrm{L}$ (table 4). The most abundant THM species formed were $\mathrm{CHBr}_{2} \mathrm{Cl}$ and $\mathrm{CHBr}_{3}$ (app. 2; vials GR02965-GR02968). These findings are consistent with the results of a 2002 USGS/CDC investigation of tap-water quality in the Fallon area. In 23 samples of water from taps in Fallon, $\mathrm{CHBr}_{3}$ concentrations consistently were the highest (1.62-16.5 $\mu \mathrm{g} / \mathrm{L})$ followed by $\mathrm{CHBr}_{2} \mathrm{Cl}(0.5-1.86$ $\mu \mathrm{g} / \mathrm{L}$; Ralph Seiler, USGS, written commun., 2005).
The concentration of bromine atoms incorporated in the THM was equivalent to an average bromide concentration of $45 \mu \mathrm{g} / \mathrm{L}$. For comparison, bromide concentrations in water samples from the basalt aquifer are approximately $180 \mu \mathrm{g} / \mathrm{L}$ (Maurer and Welch, 2001, p. 70). Bromide reacts with free chlorine to produce reactive bromine species that then react with DOC to form brominated THM species. The reactive bromine species react more rapidly with DOC and form more THM than free chlorine does; thus, high bromide concentrations increase THMFP of a water sample (Morris and Baum, 1978; Symons and others, 1993; Crepeau and others, 2004).

In the experiment using ground water, about 25 percent of the bromide in the ground water was incorporated into the THM. Much of the remaining bromide likely was incorporated into other halogenated organic compounds that were not measured in this study. THM accounts for only about 20 to 50 percent of the total mass of halogenated organic compounds formed during chlorination of natural water samples (Rostad and others, 2000; Reckhow and Singer, 1990). Because bromide has more than twice the molar weight than chloride, waters with high bromide concentrations yield higher THM concentrations on a mass basis. The presence of bromide is important because current USEPA regulations are written in terms of mass concentrations of THMs (U.S. Environmental Protection Agency, 1998). The surface water from the S-Line Canal contains relatively little bromide; thus, signifi-

\section{Table 4. Conditions and results for experiments using chlorinated water only}

[Abbreviations: $\mathrm{Cl}_{2}$, free chlorine; DOC, dissolved organic carbon; THM, trihalomethane; STHMFP, specific trihalomethane formation potential; mg/L, milligrams per liter; $\mu \mathrm{g} / \mathrm{L}$, micrograms per liter; mM/M, millimoles THM per mole DOC; $\mu \mathrm{M} / \mathrm{L}$, micromoles per liter; std units, standard units; na, not analyzed. Values rounded to three significant figures]

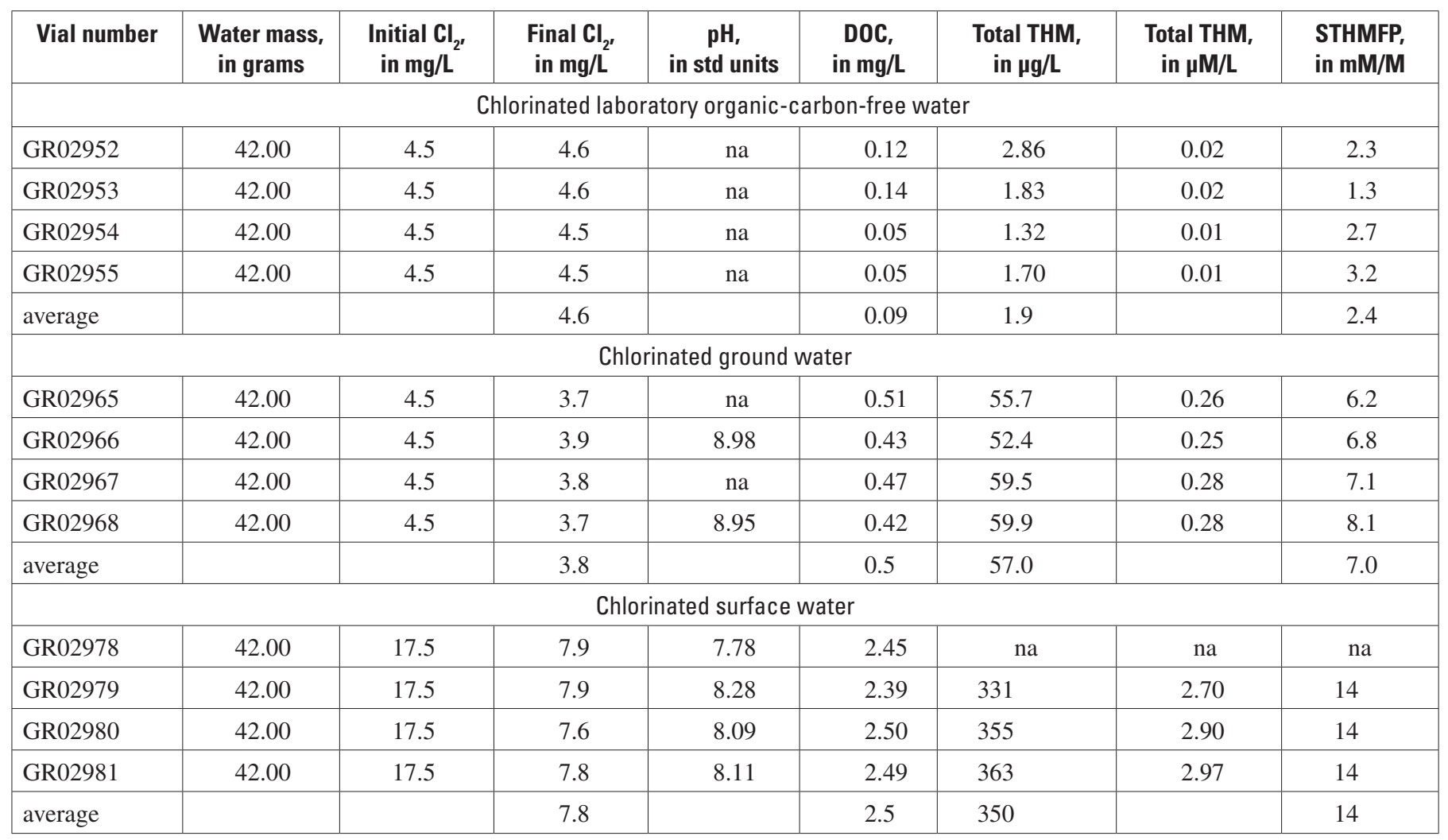


cant amounts of brominated THM would form only if treated surface water mixed with ground water in the aquifer prior to exhaustion of free chlorine.

The average DOC concentration of the chlorinated surface-water samples was $2.5 \mathrm{mg} / \mathrm{L}$, about five times that of the chlorinated ground-water samples (table 4). The average total THM was $350 \mu \mathrm{g} / \mathrm{L}$ and 93 percent of the THM was $\mathrm{CHCl}_{3}$ (app. 3; vials GR02978-GR02981), reflecting the low bromide concentration of the surface water. However, the chlorine concentrations used in this experiment were greater than generally would be used during drinking-water treatment. Actual residual free-chlorine concentrations required by regulations are in the range from 0.5 to $2 \mathrm{mg} / \mathrm{L}$ in the drinking-water distribution system. Because residence time in the distribution system may vary from hours to more than 10 days depending on the size, design, and operation of the system (Clark, 2000), the amount of chlorine required and the amount of THM formation may be highly variable, and is often less than a standard THMFP measured in the laboratory.

The amount of THM produced, normalized to the DOC concentration (defined earlier as STHMFP), provides information about the composition of the DOC present in the ground- and surface-water samples. STHMFP is a measure of the average propensity of carbon atoms in the DOC to form THMs, and it varies between approximately 3 and $18 \mathrm{mM} / \mathrm{M}$ in most water samples (Fujii and others, 1998; Weishaar and others, 2003; Fram and others, 1999). The average STHMFP values of the ground- and surface-water samples are 7.0 and $14 \mathrm{mM} / \mathrm{M}$, respectively (table 4 ), indicating that the chemical compositions of the DOC in the two samples were very different. Even if the THM concentration for the surface-water sample is reduced to account for the difference in residual free-chlorine concentrations between the ground-water and surface-water experiments, the STHMFP of the surface-water sample is still much greater than the STHMFP of the groundwater sample. The $\mathrm{pH}$ was allowed to vary freely in these experiments, although it did not change significantly after chlorination for either water sample. Higher $\mathrm{pH}$ values favor THM formation over haloacetic acid formation (Reckhow and Singer, 1985). Thus, the higher $\mathrm{pH}$ value of the ground-water sample (9.1) compared to the surface-water sample (8.1) may have resulted in proportionally more THM formation in the ground-water sample, although for this $\mathrm{pH}$ range, the effect is small.

The difference in STHMFP values for ground- and surface-water samples in this study is similar to the differences observed in other studies. For example, ground water and surface water sampled during aquifer storage and recovery tests in Lancaster, CA, had STHMFP values of 7.3 and $9.9 \pm$ $0.7 \mathrm{mM} / \mathrm{M}$, respectively (Fram and others, 2003).

As stored surface water mixes with the native ground water, the resulting $\mathrm{pH}$ will be less than that of the native ground water, and greater than that of the surface water. Because the potential for THM formation is greater at high $\mathrm{pH}$ and less at low pH (Reckhow and Singer, 1985), the potential for THM formation may be somewhat less than that measured for the ground-water samples, and somewhat greater than that measured for the surface-water samples. If the $\mathrm{pH}$ of stored water is adjusted to lower values for arsenic treatment, as suggested by Welch and others (2003, p. 403-419), the potential for THM formation also would decrease, especially if the $\mathrm{pH}$ was lowered prior to chlorination. Increased pumping from the basalt aquifer may induce flow of water with high bromide concentrations from the underlying sedimentary aquifer into the basalt aquifer. If this occurs, THM formation potential from recharge of treated surface water would increase if ground water with high bromide concentration contacts stored water with residual free chlorine.

\section{Water and rocks}

Mixtures of water, rock chips ( $<1.5 \mathrm{~cm}$ diameter), and chlorine produced very complicated results because there were multiple processes competing for the free chlorine. In addition to reacting with DOC and bromide in the water, the free chlorine reacted with the rock material. Reactions with the rock consumed significant amounts of chlorine and also released significant amounts of organic carbon from the rock, thus increasing the DOC concentration of the water.

Storage of treated surface water in the basalt aquifer will produce mixtures of the surface water and native ground water. Thus, experimental results from the surface- and ground-water samples provide end-member examples of the potential range of DOCs and THMs that may be produced from storage of chlorinated surface water.

The greatest THM concentrations were obtained from mixtures of surface water and $\mathrm{RH}$ rock samples. Chlorinated ground-water and rock mixtures produced THMs ranging from 97.4 to $347 \mu \mathrm{g} / \mathrm{L}$ for RH samples (table 5), 15.8 to $73.9 \mu \mathrm{g} / \mathrm{L}$ for test hole DB-1 samples (table 6), and 104 to $425 \mu \mathrm{g} / \mathrm{L}$ for test hole DB-4 samples (table 7). Chlorinated surface-water and rock mixtures produced THMs ranging from 335 to 909 $\mu \mathrm{g} / \mathrm{L}$ for RH samples (table 5), 128 to $620 \mu \mathrm{g} / \mathrm{L}$ for test hole DB-1 samples (table 6), and 343 to $846 \mu \mathrm{g} / \mathrm{L}$ for test hole DB-4 samples (table 7). The greatest values were often, but not always, associated with the amount of residual free chlorine at the end of the incubation periods (tables 5-7). Similarly, the greatest values were often, but not always, associated with samples having the greater rock:water ratio (tables 5-7).

Compared to results using water only, DOC concentrations in experiments with rock:water ratios of approximately 0.88 increased by about 14,7 , and $4 \mathrm{mg} / \mathrm{L}$ with RH, DB-1, DB-4 samples, respectively (fig. 4). The amount of DOC increase was relatively independent of the water type, but was proportional to the rock: water ratio indicating that the amount of carbon released per gram of rock was relatively constant for each rock type. For the experiments using laboratory organic-carbon-free water, samples from RH, DB-1, and DB-4 released an average of $15.3 \pm 1.2,9.4 \pm 2.3$, and $4.9 \pm 1.1 \mu \mathrm{g}$ of organic carbon per gram of rock, respectively (tables 5-7). The amount of organic carbon released from the rock chips in the chlorinated vials was two and a half to five times the 
Table 5. Conditions and results for experiments using rock samples from Rattlesnake Hill and chlorinated water

[Abbreviations: $\mathrm{Cl}_{2}$, free chlorine; DOC, dissolved organic carbon; THM, trihalomethane; STHMFP, specific trihalomethane formation potential; OC, organic carbon; g, grams; mg/L, milligrams per liter; $\mu \mathrm{g} / \mathrm{L}$, micrograms per liter; mM/M, millimoles THM per mole DOC; $\mu \mathrm{M} / \mathrm{L}$, micromoles per liter; std units, standard units; na, not analyzed. Values rounded to three significant figures]

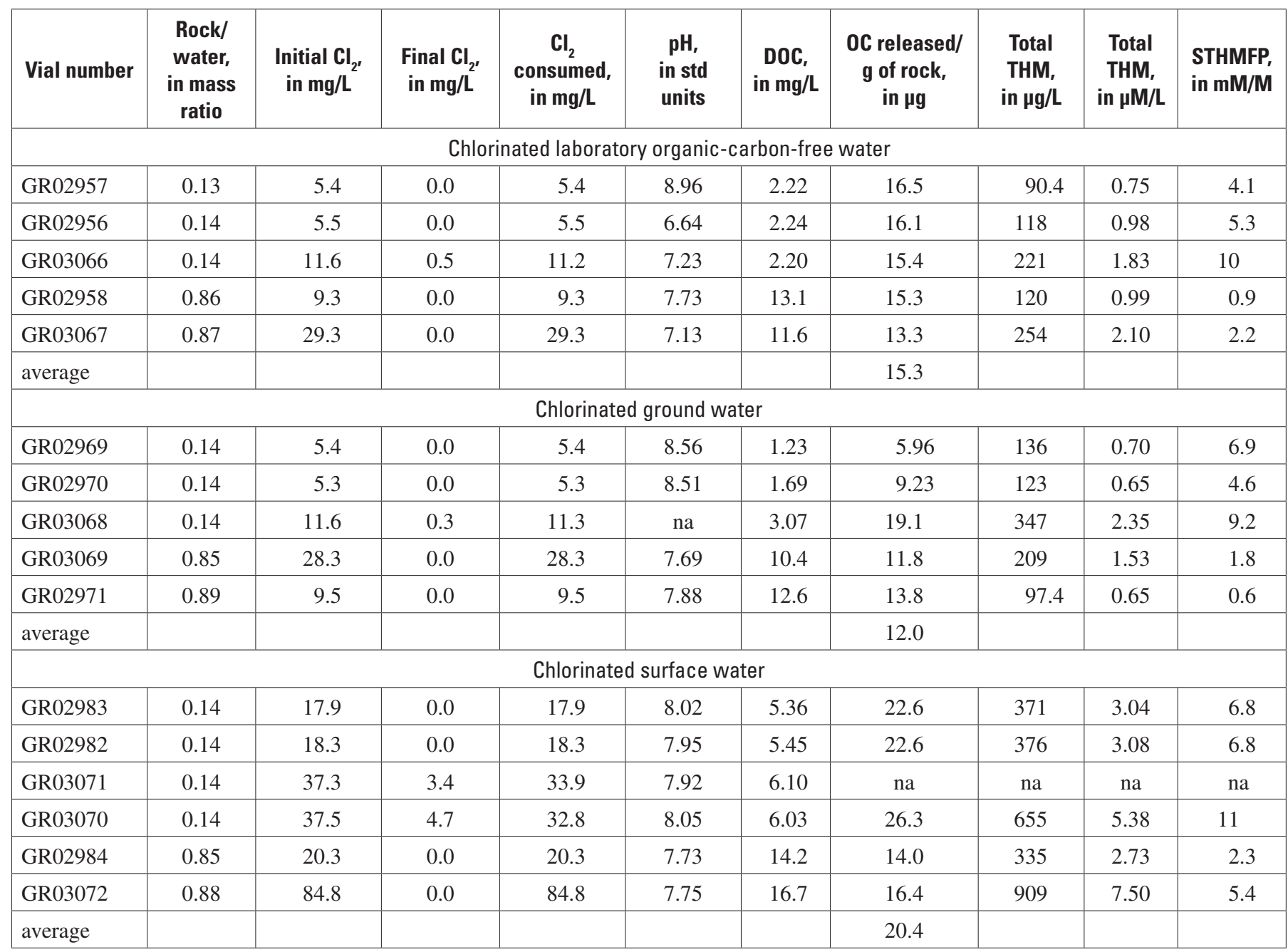

amount released from the rock chips in vials without chlorine, but still represented only 4 to 7 percent of the total amount of organic carbon in the rocks (table 2). The remaining organic carbon may reside in sites within the rock chips that were inaccessible to water or may be insoluble under the conditions of the experiments.

The organic carbon in the rocks is most likely associated with the secondary minerals that line vesicles in the rocks. $\mathrm{X}$-ray diffraction analyses indicated that the material lining vesicles in other samples of the Fallon basalt was composed of calcite, quartz, phillipsite, and clay minerals (Lico and Seiler, 1994). Based on examination of thin sections, vesicles in rock samples RH, DB-1, and DB-4 were lined primarily with a yellowish, finely crystalline clay that was petrographically identified as nontronite, a ferric-iron rich smectite (Dr. Peter Schiffman, University of California, Davis, oral commun.,
2004). Nontronite has been observed intergrown with polysaccharides exuded from microbial cells and produced in experimental mixtures of polysaccharides and iron- and silica-rich ground water (Ueshima and Tazaki, 2001). Microbial surfaces have been identified as sites for nucleation and growth of secondary clay minerals during alteration of basaltic glasses (Konhauser and others, 2002; Fisk and others, 2003). Based on examination of thin sections, the clay linings were thickest in the vesicles of rock sample RH. Sample RH also contained the greatest concentration of organic carbon (table 2). This clay possibly contains microbial biomass, and it is likely that chlorination of the microbial biomass releases organic carbon into solution. Because the RH samples were taken from a surface outcrop, they also may contain lichen and other potential sources of organic carbon. 
Table 6. Conditions and results for experiments using rock samples from DB-1 and chlorinated water

[Abbreviations: $\mathrm{Cl}_{2}$, free chlorine; DOC, dissolved organic carbon; THM, trihalomethane; STHMFP, specific trihalomethane formation potential; OC, organic carbon; g, grams; mg/L, milligrams per liter; $\mu \mathrm{g} / \mathrm{L}$, micrograms per liter; mM/M, millimoles THM per mole DOC; $\mu \mathrm{M} / \mathrm{L}$, micromoles per liter; std units, standard units; na, not analyzed. Values rounded to three significant figures]

\begin{tabular}{|c|c|c|c|c|c|c|c|c|c|c|}
\hline Vial number & $\begin{array}{c}\text { Rock/ } \\
\text { water, } \\
\text { in mass } \\
\text { ratio }\end{array}$ & $\begin{array}{l}\text { Initial } \mathrm{Cl}_{2^{\prime}} \\
\text { in } \mathrm{mg} / \mathrm{L}^{-}\end{array}$ & $\begin{array}{l}\text { Final } \mathrm{Cl}_{\mathbf{2}^{\prime}} \\
\text { in } \mathrm{mg} / \mathrm{L}^{2}\end{array}$ & $\begin{array}{c}\mathrm{Cl}_{2} \\
\text { consumed, } \\
\text { in } \mathrm{mg} / \mathrm{L}\end{array}$ & $\begin{array}{l}\mathrm{pH} \text {, } \\
\text { in std } \\
\text { units }\end{array}$ & $\begin{array}{c}\text { DOC, } \\
\text { in } \mathrm{mg} / \mathrm{L}\end{array}$ & $\begin{array}{l}\text { OC released/ } \\
\text { g of rock, } \\
\text { in } \mu \mathrm{g}\end{array}$ & $\begin{array}{c}\text { Total } \\
\text { THM, } \\
\text { in } \mu \mathrm{g} / \mathrm{L}\end{array}$ & $\begin{array}{c}\text { Total } \\
\text { THM, } \\
\text { in } \mu \mathrm{M} / \mathrm{L}\end{array}$ & $\begin{array}{l}\text { STHMFP, } \\
\text { in } \mathrm{mM} / \mathrm{M}\end{array}$ \\
\hline \multicolumn{11}{|c|}{ Chlorinated laboratory organic-carbon-free water } \\
\hline GR02959 & 0.14 & 5.4 & 0.4 & 5.0 & na & 1.57 & 11.2 & 33.3 & 0.28 & 2.1 \\
\hline GR02960 & 0.14 & 5.5 & 0.4 & 5.1 & na & 1.61 & 11.4 & 29.6 & 0.25 & 1.8 \\
\hline GR02961 & 0.86 & 9.4 & 0.6 & 8.8 & na & 6.27 & 7.28 & 23.1 & 0.19 & 0.4 \\
\hline GR03073 & 0.87 & 29.2 & 0.7 & 28.5 & 9.23 & 6.57 & 7.53 & 51.6 & 0.43 & 0.8 \\
\hline average & & & & & & & 9.4 & & & \\
\hline \multicolumn{11}{|c|}{ Chlorinated ground water } \\
\hline GR02972 & 0.14 & 5.5 & 0.0 & 5.5 & 9.00 & 1.43 & 7.56 & 34.2 & 0.17 & 1.5 \\
\hline GR02973 & 0.14 & 5.4 & 0.0 & 5.4 & 8.94 & 2.20 & 12.8 & 15.8 & 0.10 & 0.5 \\
\hline GR03074 & 0.14 & 11.5 & 0.1 & 11.4 & 8.54 & 1.59 & 8.31 & 73.9 & 0.39 & 2.9 \\
\hline GR02974 & 0.85 & 9.3 & 0.0 & 9.3 & na & 7.20 & 7.99 & 17.9 & 0.13 & 0.2 \\
\hline GR03075 & 0.90 & 30.1 & 0.0 & 30.1 & 8.39 & 6.64 & 6.93 & 63.9 & 0.40 & 0.7 \\
\hline average & & & & & & & 8.72 & & & \\
\hline \multicolumn{11}{|c|}{ Chlorinated surface water } \\
\hline GR02985 & 0.14 & 18.1 & 0.0 & 18.1 & 8.61 & 4.12 & 13.1 & 210 & 1.70 & 5.0 \\
\hline GR03076 & 0.14 & 36.9 & 5.4 & 31.5 & 8.38 & 3.10 & 5.66 & 403 & 3.29 & 13 \\
\hline GR03077 & 0.14 & 37.7 & 5.9 & 31.8 & 8.30 & 3.03 & 5.15 & 343 & 2.80 & 11 \\
\hline GR02986 & 0.14 & 18.5 & 0.0 & 18.5 & 8.47 & 4.50 & 15.5 & 241 & 1.96 & 5.2 \\
\hline GR03078 & 0.32 & 71.7 & 6.1 & 65.6 & 8.28 & 5.19 & 9.02 & 620 & 5.14 & 12 \\
\hline GR02987 & 0.89 & 21.2 & 0.0 & 21.2 & 9.00 & 10.3 & 9.01 & 128 & 1.03 & 1.2 \\
\hline average & & & & & & & 9.6 & & & \\
\hline
\end{tabular}

The results from experiments containing chlorinated laboratory water and rock chips can be used to assess the compositional character of the organic carbon released from the rocks by contact with chlorine. Because the average DOC and total THM concentrations in the laboratory water alone were 0.09 $\mathrm{mg} / \mathrm{L}$ and $1.9 \mu \mathrm{g} / \mathrm{L}$, respectively (table 4 ), it is assumed that all of the DOC and THM in the vials with rock were produced by reaction of chlorine and the organic carbon from the rocks. THM concentrations and the amount of chlorine consumed during the incubation period for vials with rock:water ratios of approximately 0.14 are plotted in figure 5A. Fortuitously, vials containing all three rock types had similar residual free-chlorine concentrations $(0.4-0.5 \mathrm{mg} / \mathrm{L})$ at the end of the incubation period (table 5, vial GR03066; table 6, vials GR02959 and GR02960; and table 7, vial GR02963). Thus, the chlorination conditions are comparable with each other.

For vials GR03066 (RH rock), GR 02959 (DB-1 rock), GR02960 (DB-1 rock), and GR02963 (DB-4 rock), the experiments with RH consumed the most chlorine, formed the most
THM, and resulted in the greatest DOC concentration (tables 5-7). The experiments with DB-4 formed more than three times as much THM as those with DB-1, but had about the same chlorine consumption and resulted in a DOC concentration only half that of those with DB-1 (fig. 5, tables 6 and 7). The maximum STHMFP values for the organic carbon released from RH, DB-1, and DB-4 for rock:water ratios of approximately 0.14 are about $10,2.1$, and $14 \mathrm{mM} / \mathrm{M}$, respectively (tables 5-7). STHMFP values calculated from experiments that did not contain residual free chlorine at the end of the incubation period are always lower than these values (tables 5-7). These values are lower because the reactions that released organic carbon from the rocks consumed chlorine more rapidly than did the THM formation reactions, and insufficient chlorine was available to achieve maximum THM concentrations. Based on these STHMFP values, the organic carbon released from the rocks during chlorination compositionally is different than the ambient DOC in the ground water (STHMFP equal to $7.0 \mathrm{mM} / \mathrm{M}$ ). Moreover, the compositions 
Table 7. Conditions and results for experiments using rock samples from DB-4 and chlorinated water

[Abbreviations: $\mathrm{Cl}_{2}$, free chlorine; DOC, dissolved organic carbon; THM, trihalomethane; STHMFP, specific trihalomethane formation potential; OC, organic carbon; g, grams; mg/L, milligrams per liter; $\mu \mathrm{g} / \mathrm{L}$, micrograms per liter; mM/M, millimoles THM per mole DOC; $\mu \mathrm{M} / \mathrm{L}$, micromoles per liter; std units, standard units; na, not analyzed. Values rounded to three significant figures]

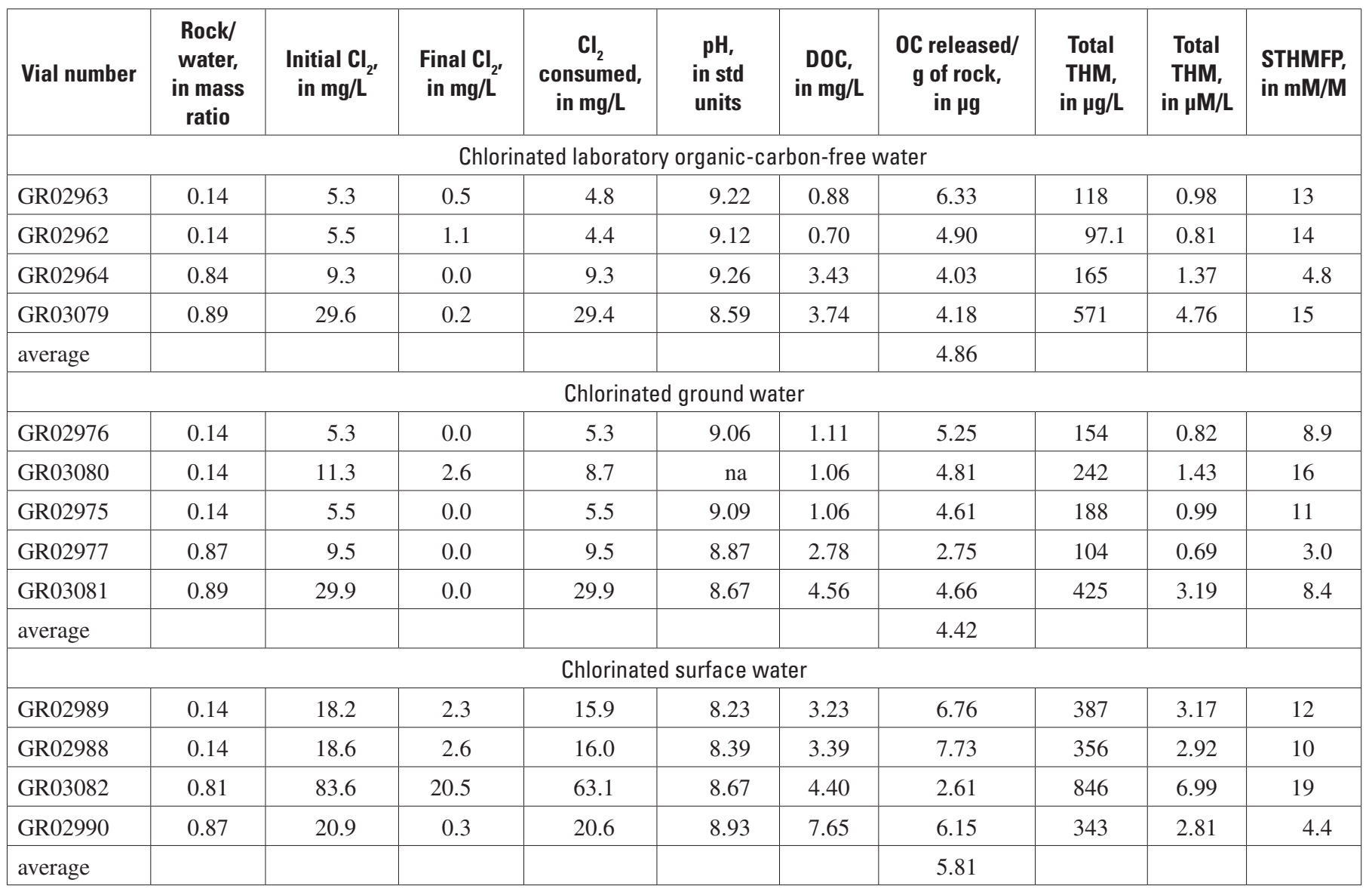

of the organic carbon released from the three rocks are different. The reasons for these differences cannot be determined from the data collected in this study.

The amount of THM formed was not directly related to the DOC concentration or to the amount of chlorine consumed during the experiment, because of the competition between different types of reactions consuming chlorine. Reactions that released organic carbon from the rocks appear to have occurred more rapidly than the reactions between chlorine and DOC to form THM. For example, the three chlorinated vials containing samples from RH and laboratory organiccarbon-free water in a rock:water ratio of approximately 0.14 all resulted in DOC concentrations of about $2.2 \mathrm{mg} / \mathrm{L}$ at the end of the incubation period (table 5; vials GR02956, GR02957, and GR03066). However, the THM concentration in the vial that contained residual free chlorine at the end of the incubation period, vial GR03066, was about twice as great as the concentration in the other two vials in which no residual free chlorine remained. The increase in DOC concen- tration due to release of organic carbon from the rocks was independent of the amount of chlorine consumed during the experiment and of the residual free-chlorine concentration at the end of the experiment (fig. 4; tables 5-7). No experiments were done with very low initial free chlorine doses; thus, the minimum concentration of chlorine required to release organic carbon from the rocks is unknown.

All three rock types are capable of consuming large amounts of chlorine. The chlorine consumption capacity of the rocks controls how much of the aquifer may be exposed to free chlorine when chlorinated surface water is used to recharge the aquifer. The chlorine consumption capacity of the rock material can be estimated as the total amount of chlorine consumed in the vial, minus the amount of chlorine consumed by the surface water in the vial, all divided by the mass of rock in the vial. This calculation was made for all vials containing surface water and rock chips that had residual free chlorine at the end of the reaction period (tables 5-7). Chlorine consumption capacities for RH, DB-1, and DB-4 were estimated to be 0.17 , 

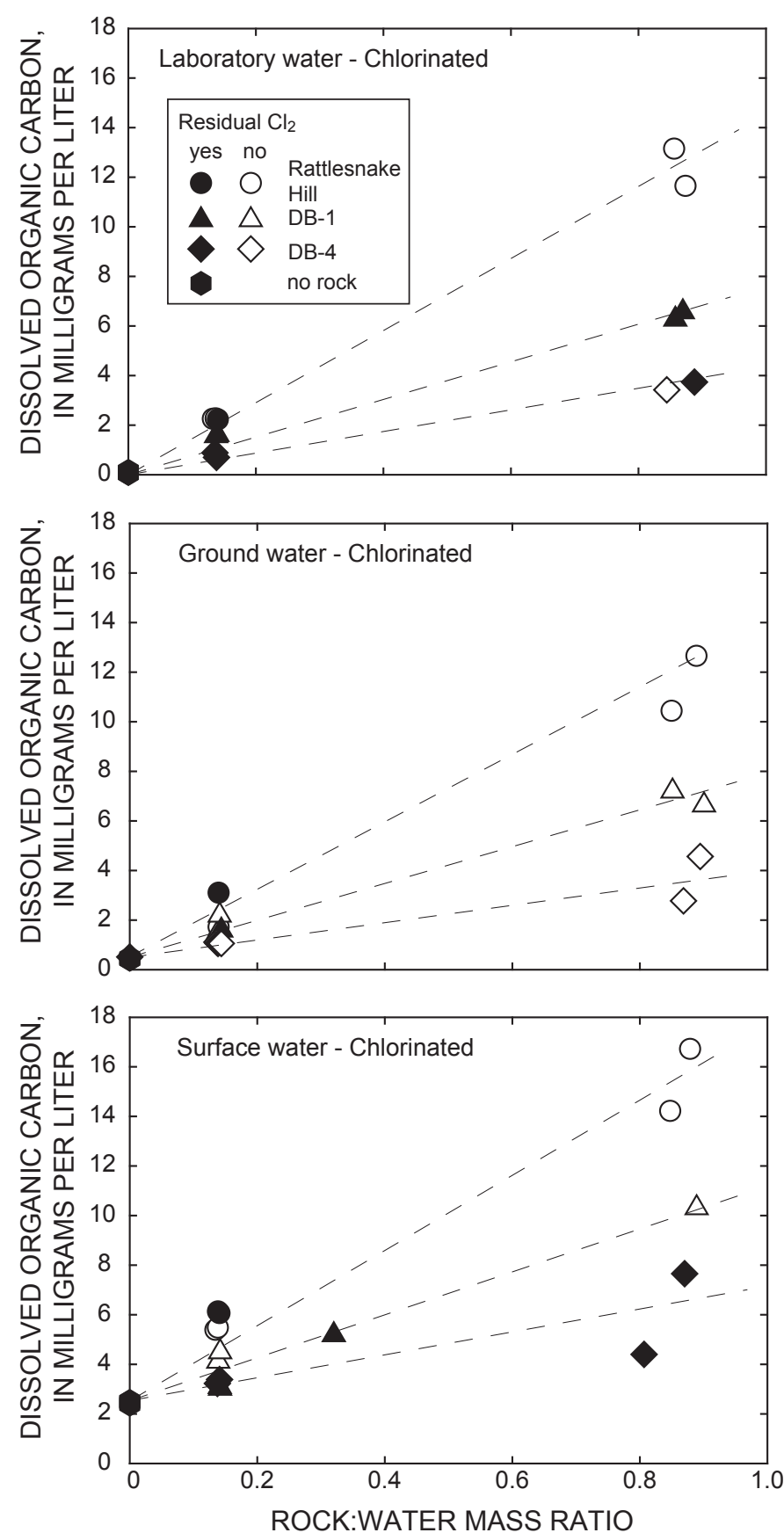

Figure 4. Dissolved-organic-carbon (DOC) concentrations in samples of organic-carbon-free laboratory water, ground water from the Fallon basalt aquifer, and surface water from the S-Line Canal in Fallon, NV, equilibrated for 20 days with free chlorine at $25^{\circ} \mathrm{C}$ alone and with three different rock samples from the Fallon basalt aquifer. DOC concentrations in the water increase as the rock:water ratio increases for all three water samples and for all three rock samples. DOC concentrations increase linearly by the same amount whether or not there is residual free chlorine present at the end of the incubation period (see dashed lines).
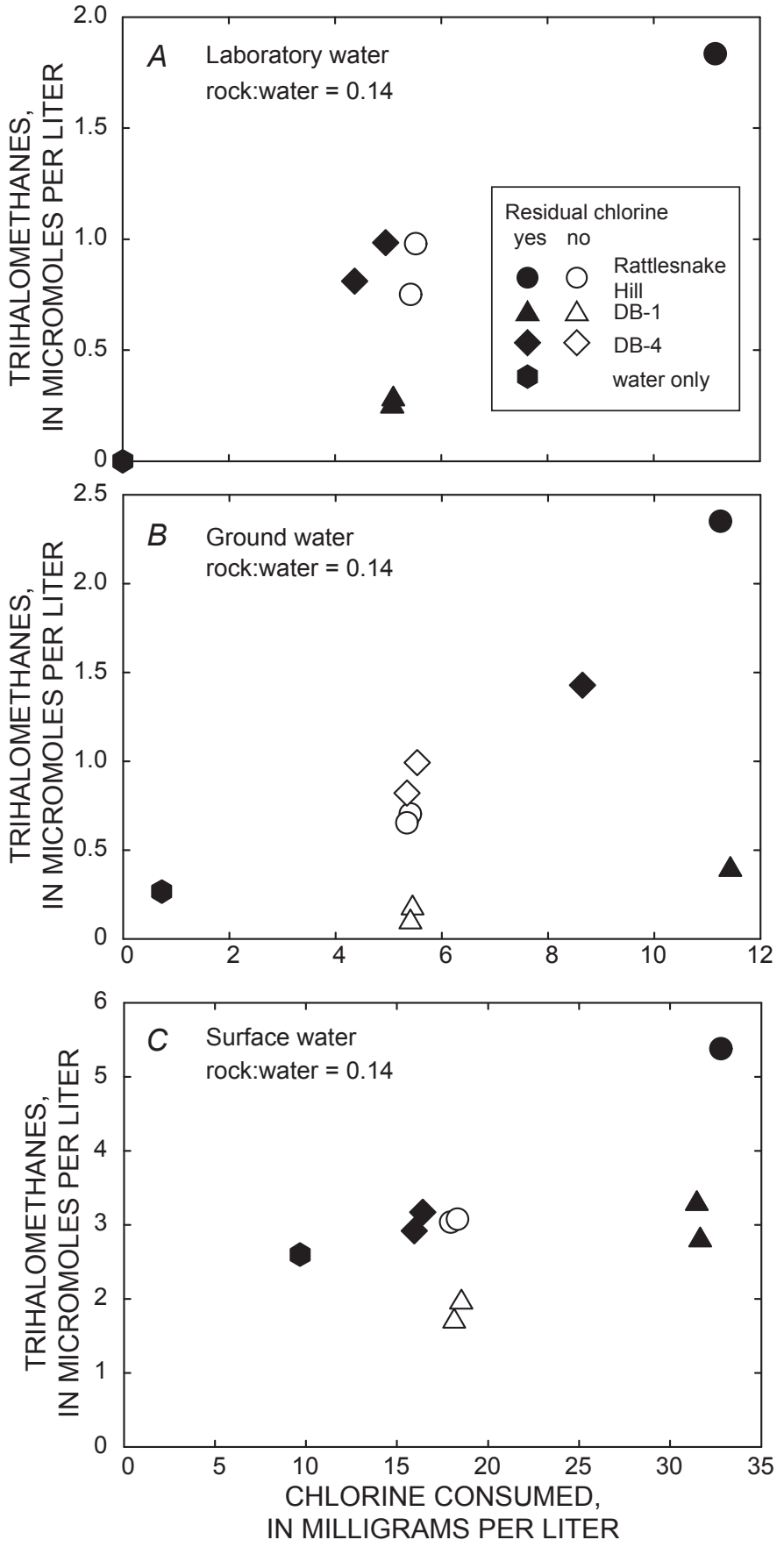

Figure 5. Trihalomethane (THM) concentrations in samples of $(A)$ organic-carbon-free laboratory water, $(B)$ ground water from the Fallon basalt aquifer, and $(C)$ surface water from the $S$-Line Canal in Fallon, NV, equilibrated for 20 days with free chlorine at $25^{\circ} \mathrm{C}$ alone and with three different rock samples from the Fallon basalt aquifer (rock:water ratios of approximately 0.14). THM concentrations do not increase linearly as the concentration of free chlorine consumed in the experiment increases. 
0.06 , and $0.17 \mathrm{mg} \mathrm{Cl}_{2} / \mathrm{g}$ of rock, respectively. Because it is not known if the 20-day period was sufficient for all reactions to be completed, these calculated consumption capacities may be minimum values.

The chlorine consumption capacity of the rocks likely results from reactions between chlorine and the inorganic minerals as well as between chlorine and the minute amounts of organic matter in the rocks. The Fallon basalt contains abundant ferrous iron in clinopyroxene, olivine, and iron-oxide mineral phases. The forms of dissolved chlorine present in chlorinated water, hypochlorous acid and hypochlorite ion, are both strong oxidants and may react with ferrous iron in the mineral phases to form ferric iron.

In an operating storage-recovery system, THM formation may be limited because the rock material consumes chlorine more rapidly than at least some of the THM formation reactions. For example, chlorinated mixtures of ground water or surface water and DB-1 sample produced more THM than did the chlorinated water alone, as long as residual free chlorine was present at the end of the incubation period indicating sufficient chlorine for all of the chlorine consuming reactions (fig. 5). However, if no chlorine was present, the amount of THM formed was less than the amount formed in chlorinated water alone (fig. 5), indicating that reactions between chlorine and the rock were faster than many of the THM formation reactions. THM-formation reactions have complex kinetics because DOC contains distinct pools of THM precursors that react at different rates. Some THM-precursor sites react completely with 5 minutes of chlorination, and others are still producing THMs after several weeks of contact with chlorine (Gallard and von Gunten, 2002).

Because the relative rates of all the reactions consuming chlorine are unknown, additional experiments would be needed to determine how much THM formation would occur at the chlorine concentrations that may be present in an operating storage-recovery system. Actual residual freechlorine concentrations required by regulations range from 0.5 to $2 \mathrm{mg} / \mathrm{L}$ in the drinking water distribution system. Because residence time in the distribution system varies from hours to more than 10 days depending on the size, design, and operation of the system (Clark, 2000), the amount of chlorine required may be highly variable.

The chlorine consumption capacity of the rock can be used to evaluate DOC release and THM formation in an actual storage-recovery operation. Assuming the chlorine consumption capacity is $0.17 \mathrm{mg} \mathrm{Cl}_{2} / \mathrm{g}$ of rock, and that water is injected into a well screened for a $200 \mathrm{ft}$ interval in the basalt aquifer, a cylinder of basalt with a density of $3.1 \mathrm{~g} / \mathrm{cm}^{3}$ and a radius of $1 \mathrm{ft}$ surrounding the well would consume $9.4 \mathrm{~kg}$ of chlorine. Assuming that the chlorine concentration of surface water leaving a treatment plant may have about $1 \mathrm{mg} / \mathrm{L}$ free chlorine, and that half of that chlorine would be consumed by reaction with DOC in the surface water during transit and injection, 18.7 million liters of water would be required to supply the $9.4 \mathrm{~kg}$ of chlorine consumed by the cylinder of rock $200 \mathrm{ft}$ high and $1 \mathrm{ft}$ in radius around the well bore. If the effec- tive porosity of the basalt is about 10 percent, this $18.7 \mathrm{ML}$ of water would recharge a cylinder of rock with a radius of $105 \mathrm{ft}$ and a height of $200 \mathrm{ft}$. By this calculation, the volume of rock surrounding the well bore that would consume the chlorine in the injected water is only about 0.009 percent of the volume the aquifer filled with the injected water. Thus, very little of the total volume of aquifer recharged by the treated surface water would be exposed to free chlorine. Without exposure to free chlorine, excess DOC would not be released from the rocks, and additional THM formation would not occur.

Additional laboratory tests that would provide useful information prior to design of an operating storage-recovery system include a series of tests using (1) varying levels of chlorination, (2) varying lengths of reaction periods, from 24 hours to 30 days or more, (3) repeated cycles of chlorination, and (4) flow-through columns. Using varying levels of chlorination (mostly lower concentrations) would provide more realistic estimates of THM concentrations under conditions closer to those in an operating system. Varying the lengths of reaction periods and repeated chlorination applications would give the rates of DOC release and the maximum DOC production from the rocks. Experiments using flow-through columns would allow simulation of conditions under actual injection or infiltration and subsequent pumping of stored water.

\section{Conclusions}

The results of the experiments indicate that the amount of organic carbon released from the rocks during successive cycles of recharge, storage, and recovery of chlorinated surface water may be small. In these experiments, the mass of organic carbon released per gram of rock did not appear to be a function of free-chlorine concentration. This indicates that continued application of more chlorine (i.e., more cycles) may not result in the release of more and more organic carbon. The first introduction of free chlorine into the aquifer may release all of the soluble organic carbon from the rocks. Moreover, the chlorine demand of the rocks is so large that all of the free chlorine in the entire volume of recharged water likely would be consumed by only a very small volume of the aquifer surrounding an injection well, or beneath an infiltration bed. The majority of the volume of the aquifer filled by the stored water likely would never come in contact with free chlorine. Thus, increases in DOC observed in these experiments likely would only occur in a very small volume of the stored water. The mass of organic carbon added by this mechanism would represent an insignificant amount in the total volume of water stored.

When chlorinated surface water is stored in the basalt aquifer, increases in THMs for the entire volume of water stored likely will be considerably less than those measured in these experiments. In these experiments, the organic carbon released from the rocks by reaction with chlorine resulted in large increases in the DOC concentration of the water, and 
THM concentrations from 335 to $909 \mu \mathrm{g} / \mathrm{L}$ for surface water equilibrated with rock samples from Rattlesnake Hill. However, as stated above, such large increases in DOC concentration may not occur during actual storage and recovery cycles. In addition, the concentration of chlorine in the surface water will be lower than used in these experiments. Without the increase in DOC concentration, the high concentrations of THM would not be expected. Field experiments made at a small scale in an isolated part of the basalt aquifer would aid in the design of an operational storage-recovery system.

\section{References Cited}

Bauer, D.J., Foster, B.J., Joyner, J.D., and Swanson, R.A., 1996, Water resources data, Nevada, water year 1995: U.S. Geological Survey Water-Data Report NV-95-1, 734 p.

Bird, S.M., Fram, M.S., and Crepeau, K.L., 2003, Method of analysis by the U.S. Geological Survey California District Sacramento Laboratory - Determination of dissolved organic carbon in water by high-temperature catalytic oxidation, method validation, and quality-control practices: U.S. Geological Survey Open-File Report 03-366, 14 p.

Bostic, R.E., Kane, R.L., Kipfer, K.M., and Johnson, A.W., 1997, Water resources data, Nevada, water year 1996: U.S. Geological Survey Water-Data Report NV-96-1, 611 p.

Clark, R., 2000, Water-quality modeling case studies, in Mays, L.W., ed., Water Distribution Systems Handbook: New York, McGraw-Hill, p. 13.1-13.49.

Crepeau, K.L., Fram, M.S., and Bush, Noel, 2004, Method of analysis by the U.S. Geological Survey California District Sacramento Laboratory - Determination of trihalom ethane formation potential, method validation, and quality-control practices: U.S. Geological Survey Scientific Investigations Report 2004-5003, 33 p.

Fisk, M.R., Storrie-Lombardi, M.C., Douglas, S., Popa, R., McDonald, G., and Di Meo-Savoie, C., 2003, Evidence of biological activity in Hawaiian subsurface basalts: Geochemistry Geophysics Geosystems, v. 4, no. 12, 1103, doi: 10.1029/2002GC000387.

Fram, M.S., Bergamaschi, B.A., Goodwin, K.D., Fujii, Roger, and Clark, J.F., 2003, Processes affecting the trihalomethane concentrations associated with the third injection, storage, and recovery test at Lancaster, Antelope Valley, California, March 1998 through April 1999: U.S. Geological Survey Water-Resources Investigations Report 03-4062, 72 p.
Fram, M.S., Fujii, Roger, Weishaar, J.S., Bergamaschi, B.A., and Aiken, G.R., 1999, How DOC composition may explain the poor correlation between specific trihalomethane formation potential and specific UV absorbance, in Morganwalp, D.W., and Buxton, H.T., eds., U.S. Geological Survey Toxic Substances Hydrology Program - Proceedings of the technical meeting, Charleston, South Carolina, March 8-12, 1999: U.S. Geological Survey Water-Resources Investigations Report 99-4018-B, p. 423-430.

Fujii, Roger, Ranalli, A.J., Aiken, G.R., and Bergamaschi, B.A., 1998, Dissolved organic carbon concentrations and compositions, and trihalomethane formation potentials in waters from agricultural peat soils, Sacramento-San Joaquin Delta, California: Implications for drinking-water quality: U.S. Geological Survey Water-Resources Investigations Report 98-4147, 75 p.

Gallard, H., and von Gunten, U., 2002, Chlorination of natural organic matter: kinetics of chlorination and of THM formation: Water Research, v. 36, p. 65-74.

Glancy, P.A., 1986, Geohydrology of the basalt and unconsolidated sedimentary aquifers in the Fallon area, Churchill County, Nevada: U.S. Geological Survey Water Supply Paper 2263, 62 p.

Hach Company, 1997, Hach Water Analysis Handbook (3d ed.): Loveland, CO, Hach Company, 1309 p.

Konhauser, K.O., Schiffman, P., and Fisher, Q.J., 2002, Microbial mediation of authigenic clays during hydrothermal alteration of basaltic tephra, Kilauea Volcano: Geochemistry Geophysics Geosystems, v. 3, no. 12, 13 p.

Larson, R.A., and Rockwell, A.L., 1979, Chloroform and chlorophenol production by decarboxylation of natural acids during aqueous chlorination: Environmental Science and Technology, v. 13, no. 3, p. 325-329.

Lico, M.S., and Seiler, R.L., 1994, Ground-water quality and geochemistry, Carson Desert, western Nevada: U.S. Geological Survey Open-File Report 94-31, 91 p.

Maurer, D.K., 2002, Results of test drilling the basalt aquifer near Fallon, Nevada: U.S. Geological Survey Fact Sheet FS-048-02, 4 p.

Maurer, D.K., and Welch, A.H., 2001, Hydrogeology and geochemistry of the Fallon basalt and adjacent aquifers, and potential sources of basalt recharge in Churchill County, Nevada: U.S. Geological Survey Water-Resources Investigations Report 01-4130, 72 p. 
Morris, J.C., and Baum, B., 1978, Precursors and mechanisms of haloform formation in the chlorination of water supplies, in Jolley, R.L., Gorchev, Hend, and Hamilton, D.H., Jr., eds., Water chlorination, environmental impact and health effects, volume 2: Proceedings of the second conference on the environmental impact of water chlorination, Gatlinburg, Tennessee, October 31-November 4, 1977: Ann Arbor, MI, Ann Arbor Science Publishers, Inc., p. 29-48.

Norwood, D.L., Johnson, J.D., Chirstman, R.F., Hass, J.R., and Bobenrieth, M.J., 1980, Reactions of chlorine with selected aromatic models of aquatic humic material: Environmental Science and Technology, v. 14, no. 2, p. 187-190.

Rebenne, L.M., Gonzalez, A.G., and Olson, T.M., 1996, Aqueous chlorination kinetics and mechanism of substituted dihydroxybenzenes: Environmental Science and Technology, v. 30, no. 7, p. 2235-2242.

Reckhow, D.A., and Singer, P.C., 1985, Mechanisms of organic halide formation during fulvic acid chlorination and implications with respect to preozonation, in Jolley, R.L., Bull, R.J., Davis, W.P., Katz, S., Roberts M.H., Jr., and Jacobs, V.A., eds, Water chlorination: Chemistry, environmental impact, and health effects: Chelsea, MI, Lewis Publishers, Inc., v. 5, p. 1229-1257.

Reckhow, D.A., and Singer, P.C., 1990, Chlorination byproducts in drinking waters: From formation potentials to finished water concentrations: Journal of American Water Works Association, v. 82, no. 4, p. 173-180.

Reckhow, D.A., Singer, P.C., and Malcolm, R.L., 1990, Chlorination of humic materials: Byproduct formation and chemical interpretations: Environmental Science and Technology, v. 24, no. 22, p. 1655-1664.

Rook, J.J., 1977, Chlorination reactions of fulvic acids in natural waters: Environmental Science and Technology, v. 11 , no. 5 , p. $478-482$.

Rostad, C.E., Martin, B.S., Barber, L.B., Leenheer, J.A., and Daniel, S.R., 2000: Effect of a constructed wetland on disinfection byproducts: Removal processes and production of precursors: Environmental Science and Technology, v. 34, no. 13 , p. $2703-2710$.

Symons, J.M., Krasner, S.W., Simms, L.A., and Sclimenti, M., 1993, Measurement of THM and precursor concentrations revisited: The effect of bromide ion: Journal of the American Water Works Association, v. 85, no. 1, p. 51-62.

Thomas, J.M., McKay, W.A., Cole, E., Landmeyer, J.E., and Bradley, P.M., 2000, The fate of haloacetic acids and trihalomethanes in an aquifer storage and recovery program, Las Vegas, Nevada: Ground Water, v. 38, no. 4, p. 605-614.
Ueshima, Masato, and Tazaki, Kazue, 2001, Possible role of microbial polysaccharides in nontronite formation: Clays and Clay Minerals, v. 49, no. 14, p. 292-299.

U.S. Environmental Protection Agency, 1997, Method 440.0 Determination of carbon and nitrogen in sediments and particulates of estuarine/coastal waters using elemental analysis, in Methods for the Determination of Chemical Substances in Marine and Estuarine Environmental Matrices, 2nd edition: National Exposure Research Laboratory, Office of Research and Development, Cincinnati, Ohio, USEPA 600/R-97-072, $10 \mathrm{p}$.

U.S. Environmental Protection Agency, 1998, National primary drinking water regulations: Disinfectants and disinfection byproducts: Federal Register, December 16, 1998, v. 63, no. 241, p. 69389-69476.

U.S. Environmental Protection Agency, 2001, National primary drinking-water regulations: Arsenic and clarifications to compliance and new source contaminants monitoring; final rule: Federal Register, U.S. Code of Federal Regulations, January 22, 2001, v. 66, no. 14, p. 6975-7066.

Weishaar, J.L., Aiken, G.R., Bergamaschi, B.A., Fram, M.S., Fujii, Roger, and Mopper, Kenneth, 2003, Evaluation of specific ultraviolet absorbance as an indicator of the chemical composition and reactivity of dissolved organic carbon: Environmental Science and Technology, v. 37, no. 20, p. 4702-4708.

Welch, A.H., Stollenwerk, K.G., Maurer, D.K., and Feinson, L.S., 2003, In situ arsenic remediation in a fractured, alkaline aquifer, in Welch, A.H., and Stollenwerk, K.G., eds., Arsenic in Ground Water: Boston, MA, Kluwer Academic Publishers, $470 \mathrm{p}$.

Welch, A.H., Maurer, D.K., Lico, M.S., and McCormack, J.K., 2005, Characterization of surface-water quality and potential geochemical reactions from storage of surface water in the basalt aquifer near Fallon, Nevada: U.S. Geological Survey Scientific Investigations Report 2005-5102, 43 p., at URL <http://pubs.water.usgs.gov/ sir2005-5102>.

Wilde, F.D., and Radtke, D.B., eds., 1998, National field manual for the collection of water-quality data: Chapter A6. Field measurements: U.S. Geological Survey Techniques of Water-Resources Investigations, book 9, chap. A6, last accessed September 2004 at URL <http://pubs.water.usgs. gov/twri9A6>. 


\section{Appendixes}


Appendix 1. Conditions and results for experiments using laboratory organic-carbon-free water

[Abbreviations: $\mathrm{Cl}_{2}$, free chlorine; DOC, dissolved organic carbon; $\mathrm{CHCl}_{3}$, chloroform; $\mathrm{CHCl}_{2} \mathrm{Br}$, bromodichloromethane; $\mathrm{CHBr}_{2} \mathrm{Cl}$, dibromochloromethane; $\mathrm{CHBr}$, bromoform, $\mathrm{THM}$, trihalomethane; STHMFP, specific trihalomethane formation potential; Br-THM, bromide in THM; g, gram; mg/L, milligrams per liter; $\mu \mathrm{g} / \mathrm{L}$, micrograms per liter; mM/M, millimoles THM per mole DOC; $\mu \mathrm{M} / \mathrm{L}$, micromoles per liter; OC, organic carbon; na, not analyzed; std units, standard units; nd, not detected ( $<0.2 \mu \mathrm{g} / \mathrm{L}_{\text {for }} \mathrm{CHCl}_{3}$ and $\mathrm{CHBr}_{3}$, and $<0.1 \mu \mathrm{g} / \mathrm{L}$ for $\mathrm{CHCL} 2 \mathrm{Br}_{2}$ and $\left.\left.\mathrm{CHBr}{ }_{2} \mathrm{Cl}\right)\right]$

\begin{tabular}{|c|c|c|c|c|c|c|c|c|c|c|c|c|c|c|c|c|}
\hline $\begin{array}{c}\text { Vial } \\
\text { number }\end{array}$ & $\begin{array}{l}\text { Rock } \\
\text { source }\end{array}$ & $\begin{array}{c}\text { Rock } \\
\text { mass, } \\
\text { in grams }\end{array}$ & $\begin{array}{c}\text { Water } \\
\text { mass, } \\
\text { in grams }\end{array}$ & $\begin{array}{c}\text { Rock: } \\
\text { water } \\
\text { mass ratio }\end{array}$ & $\begin{array}{c}\text { Initial } \mathrm{Cl}_{2^{\prime}} \\
\text { in } \mathrm{mg} / \mathrm{L}\end{array}$ & $\begin{array}{c}\text { Final } \mathrm{Cl}_{2} \\
\text { in } \mathrm{mg} / \mathrm{L}\end{array}$ & $\begin{array}{c}\mathrm{pH}, \text { in } \\
\text { std units }\end{array}$ & $\begin{array}{c}\text { DOC, } \\
\text { in mg/L }\end{array}$ & $\begin{array}{l}\mathrm{CHCl}_{3^{\prime}} \\
\text { in } \mu \mathrm{g} / \mathrm{L}\end{array}$ & $\begin{array}{c}\mathrm{CHCl}_{2} \mathrm{Br} \text {, } \\
\text { in } \mu \mathrm{g} / \mathrm{L}\end{array}$ & $\begin{array}{c}\mathrm{CHBr}_{2} \mathrm{Cl} \text {, } \\
\text { in } \mu \mathrm{g} / \mathrm{L}\end{array}$ & $\begin{array}{l}\mathrm{CHBr}_{3^{\prime}} \\
\text { in } \mu \mathrm{g} / \mathrm{L}\end{array}$ & $\begin{array}{c}\text { Total THM, } \\
\text { in } \mu \mathrm{g} / \mathrm{L}\end{array}$ & $\begin{array}{c}\text { Total THM, } \\
\text { in } \mu \mathrm{M} / \mathrm{L}\end{array}$ & $\begin{array}{l}\text { STHMFP, } \\
\text { in } \mathrm{mM} / \mathrm{M}\end{array}$ & \begin{tabular}{|c|} 
OC \\
released $/ g$ \\
of rock, \\
in $\mu \mathrm{g}$
\end{tabular} \\
\hline \multicolumn{17}{|c|}{ Unchlorinated } \\
\hline GR03083 & $\mathrm{RH}$ & 15.14 & 37.91 & 0.40 & none & na & 7.82 & 1.90 & nd & nd & nd & nd & nd & nd & nd & 4.72 \\
\hline GR03086 & DB-1 & 14.09 & 37.74 & 0.37 & none & na & 9.69 & 0.88 & nd & nd & nd & nd & nd & nd & nd & 2.32 \\
\hline GR03089 & DB-4 & 15.56 & 37.08 & 0.42 & none & na & 9.50 & 0.61 & nd & nd & nd & nd & nd & nd & nd & 1.39 \\
\hline GR03092 & \multicolumn{2}{|c|}{ water only } & 42.00 & 0.00 & none & na & na & 0.05 & nd & nd & nd & nd & nd & nd & nd & na \\
\hline GR03093 & \multicolumn{2}{|c|}{ water only } & 42.00 & 0.00 & none & na & na & 0.04 & na & na & na & na & na & na & na & na \\
\hline GR03094 & \multicolumn{2}{|c|}{ water only } & 42.00 & 0.00 & none & na & na & 0.00 & na & na & na & na & na & na & na & na \\
\hline GR03095 & \multicolumn{2}{|c|}{ water only } & 42.00 & 0.00 & none & na & na & 0.00 & na & na & na & na & na & na & na & na \\
\hline \multicolumn{17}{|c|}{ Chlorinated } \\
\hline GR02957 & $\mathrm{RH}$ & 4.90 & 36.65 & 0.13 & 5.4 & 0.0 & 8.96 & 2.22 & 87.6 & 2.70 & 0.09 & 0.00 & 90.4 & 0.75 & 4.06 & 16.48 \\
\hline GR02956 & $\mathrm{RH}$ & 4.97 & 36.00 & 0.14 & 5.5 & 0.0 & 6.64 & 2.24 & 113.0 & 5.13 & 0.20 & 0.00 & 118.4 & 0.98 & 5.25 & 16.07 \\
\hline GR03066 & $\mathrm{RH}$ & 5.08 & 35.92 & 0.14 & 11.6 & 0.5 & 7.23 & 2.20 & 215 & 5.75 & 0.12 & 0.02 & 221 & 1.83 & 10.0 & 15.42 \\
\hline GR02958 & $\mathrm{RH}$ & 25.31 & 29.53 & 0.86 & 9.3 & 0.0 & 7.73 & 13.1 & 112.2 & 7.17 & 0.38 & 0.00 & 119.8 & 0.99 & 0.90 & 15.28 \\
\hline GR03067 & $\mathrm{RH}$ & 24.95 & 28.52 & 0.87 & 29.3 & 0.0 & 7.13 & 11.6 & 244 & 9.25 & 0.30 & 0.03 & 254 & 2.10 & 2.17 & 13.26 \\
\hline GR02959 & $D_{1}=1$ & & 3661 & 01 & 54 & 04 & $\mathrm{n}$ & 157 & 330 & 26 & 00 & 0 & 3 & 8 & 4 & 1123 \\
\hline GR02960 & DB-1 & 5.04 & 36.09 & 0.14 & $\begin{array}{l}5.4 \\
5.5\end{array}$ & 0.4 & na & 1.51 & $\begin{array}{l}35.0 \\
29.3\end{array}$ & $\begin{array}{l}0.20 \\
0.25\end{array}$ & 0.00 & 0.00 & $\begin{array}{l}35.5 \\
29.6\end{array}$ & $\begin{array}{l}0.28 \\
0.25\end{array}$ & $\begin{array}{l}2.14 \\
1.84\end{array}$ & \begin{tabular}{|l|}
11.25 \\
11.40
\end{tabular} \\
\hline \begin{tabular}{|l|} 
GR02961 \\
\end{tabular} & DB-1 & 25.16 & 29.33 & 0.86 & 9.4 & 0.6 & na & 6.27 & 22.9 & 0.28 & 0.00 & 0.00 & 23.1 & 0.19 & 0.37 & 7.28 \\
\hline GR03073 & DB-1 & 24.88 & 28.61 & 0.87 & 29.2 & 0.7 & 9.23 & 6.57 & 50.4 & 1.20 & 0.00 & 0.00 & 51.6 & 0.43 & 0.79 & 7.53 \\
\hline & & & & & & & & \\
\hline GR02963 & DB-4 & 5.06 & 37.23 & 0.14 & 5.3 & 0.5 & 9.22 & 0.88 & 116.6 & 1.12 & 0.02 & 0.00 & 117.7 & 0.98 & 13.4 & 6.34 \\
\hline \begin{tabular}{|l} 
GR02962 \\
GR02964
\end{tabular} & $\begin{array}{l}\text { DB-4 } \\
\text { DB-4 }\end{array}$ & $\begin{array}{r}4.99 \\
25.04\end{array}$ & $\frac{36.07}{2965}$ & $\begin{array}{l}0.14 \\
0.84\end{array}$ & $\begin{array}{l}5.5 \\
9.3\end{array}$ & $\begin{array}{l}1.1 \\
0.0\end{array}$ & $\begin{array}{l}9.12 \\
926\end{array}$ & \begin{tabular}{r|}
0.70 \\
3.43
\end{tabular} & $\begin{array}{r}95.8 \\
1595\end{array}$ & $\begin{array}{l}1.26 \\
4.88\end{array}$ & $\begin{array}{l}0.02 \\
0.38\end{array}$ & $\begin{array}{l}0.00 \\
0.02\end{array}$ & $\begin{array}{r}97.1 \\
1648\end{array}$ & $\begin{array}{l}0.81 \\
137\end{array}$ & $\begin{array}{l}13.9 \\
4.80\end{array}$ & \begin{tabular}{|l|}
4.90 \\
4.03
\end{tabular} \\
\hline GR03079 & DB-4 & 25.05 & 28.21 & 0.89 & 29.6 & 0.2 & 8.59 & 3.74 & 561 & 10.1 & 0.30 & 0.00 & 571 & 4.76 & 15.3 & 4.18 \\
\hline & \multirow{2}{*}{\multicolumn{2}{|c|}{ water only }} & & & & & & & & & & & & & & \\
\hline GR02952 & & & 42.00 & 0.00 & 4.5 & 4.6 & na & 0.12 & 2.86 & 0.00 & 0.00 & 0.00 & 2.86 & 0.02 & 2.35 & none \\
\hline GR02953 & \multicolumn{2}{|c|}{ water only } & 42.00 & 0.00 & 4.5 & 4.6 & na & 0.14 & 1.83 & 0.00 & 0.00 & 0.00 & 1.83 & 0.02 & 1.34 & none \\
\hline GR02954 & \multicolumn{2}{|c|}{ water only } & 42.00 & 0.00 & 4.5 & 4.5 & na & 0.05 & 1.32 & 0.00 & 0.00 & 0.00 & 1.32 & 0.01 & 2.66 & none \\
\hline GR02955 & \multicolumn{2}{|c|}{ water only } & 42.00 & 0.00 & 4.5 & 4.5 & na & 0.05 & 1.70 & 0.00 & 0.00 & 0.00 & 1.70 & 0.01 & 3.17 & none \\
\hline
\end{tabular}


[Abbreviations: $\mathrm{Cl}_{2}$, free chlorine; DOC, dissolved organic carbon; $\mathrm{CHCl}_{3}$, chloroform; $\mathrm{CHCl}_{2} \mathrm{Br}$, bromodichloromethane; $\mathrm{CHBr}_{2} \mathrm{Cl}$, dibromochloromethane; $\mathrm{CHBr}$, bromoform, $\mathrm{THM}$, trihalomethane; STHMFP, specific trihalomethane formation potential; Br-THM, bromide in THM; g, grams; mg/L, milligrams per liter; $\mu \mathrm{g} / \mathrm{L}$, micrograms per liter; mM/M, millimoles THM per mole DOC; $\mu \mathrm{M} / \mathrm{L}$, micromoles per liter; OC, organic carbon; na, not analyzed; std units, standard units; nd, not detected ( $<0.2 \mu \mathrm{g} / \mathrm{L}$ for $\mathrm{CHCl}_{3}$ and $\mathrm{CHBr}_{3}$, and $<0.1 \mu \mathrm{g} / \mathrm{L}$ for $\mathrm{CHCL}{ }_{2} \mathrm{Br}$ and $\left.\left.\mathrm{CHBr}{ }_{2} \mathrm{Cl}\right)\right]$

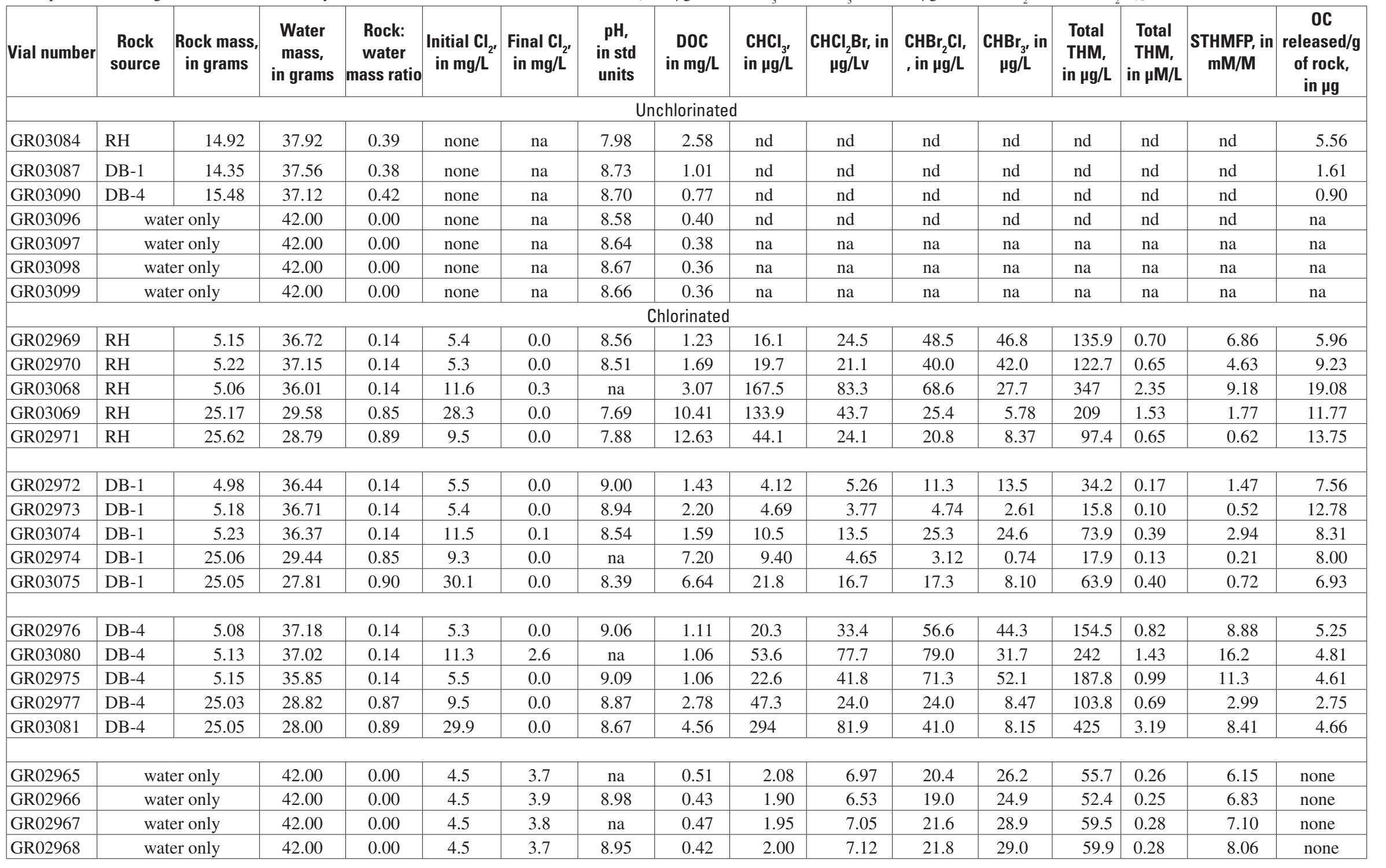


Appendix 3. Conditions and results for experiments using surface water

[Abbreviations: $\mathrm{Cl}_{2}$, free chlorine; DOC, dissolved organic carbon; $\mathrm{CHCl}_{3}$, chloroform; $\mathrm{CHCl}_{2} \mathrm{Br}$, bromodichloromethane; $\mathrm{CHBr}_{2} \mathrm{Cl}$, dibromochloromethane; $\mathrm{CHBr}_{3}$, bromoform, $\mathrm{THM}$, trihalomethane; STHMFP, specific trihalomethane formation potential; Br-THM, bromide in THM; g, grams; mg/L, milligrams per liter; $\mu \mathrm{g} / \mathrm{L}$, micrograms per liter; $\mathrm{mM} / \mathrm{M}$, millimoles THM per mole DOC; $\mu \mathrm{M} / \mathrm{L}$, micromoles per liter; OC, organic carbon; na, not analyzed; std units, standard units; nd, not detected nd, not detected $\left(<0.2 \mu \mathrm{g} / \mathrm{L}\right.$ for $\mathrm{CHCl}_{3}$ and $\mathrm{CHBr}$, and $<0.1 \mu \mathrm{g} / \mathrm{L} \mathrm{for} \mathrm{CHCL} \mathrm{Br}_{2}$ and $\left.\left.\mathrm{CHBr}{ }_{2} \mathrm{Cl}\right)\right]$

\begin{tabular}{|c|c|c|c|c|c|c|c|c|c|c|c|c|c|c|c|c|}
\hline $\begin{array}{c}\text { Vial } \\
\text { number }\end{array}$ & $\begin{array}{l}\text { Rock } \\
\text { source }\end{array}$ & \begin{tabular}{|c|} 
Rock \\
mass, \\
in grams
\end{tabular} & $\begin{array}{c}\text { Water } \\
\text { mass, } \\
\text { in grams }\end{array}$ & $\begin{array}{c}\text { Rock: } \\
\text { water } \\
\text { mass ratio }\end{array}$ & $\begin{array}{c}\text { Initial } \mathrm{Cl}_{2^{\prime}} \\
\text { in } \mathrm{mg} / \mathrm{L}\end{array}$ & $\begin{array}{c}\text { Final } \mathrm{Cl}_{2^{\prime}} \\
\text { in } \mathrm{mg} / \mathrm{L}\end{array}$ & $\begin{array}{c}\mathrm{pH}, \text { in } \\
\text { std units }\end{array}$ & $\begin{array}{c}\text { DOC, } \\
\text { in } \mathrm{mg} / \mathrm{L}\end{array}$ & $\begin{array}{l}\mathrm{CHCl}_{3} \text {, } \\
\text { in } \mu \mathrm{g} / \mathrm{L}\end{array}$ & $\begin{array}{c}\mathrm{CHCl}_{2} \mathrm{Br} \text {, } \\
\text { in } \mu \mathrm{g} / \mathrm{L}\end{array}$ & $\begin{array}{c}\mathrm{CHBr}_{2} \mathrm{Cl}, \\
\text { in } \mu \mathrm{g} / \mathrm{L}\end{array}$ & $\begin{array}{l}\mathrm{CHBr}_{3} \\
\text { in } \mu \mathrm{g} / \mathrm{L}\end{array}$ & $\begin{array}{c}\text { Total } \\
\text { THM, } \\
\text { in } \mu g / L\end{array}$ & $\begin{array}{c}\text { Total } \\
\text { THM, } \\
\text { in } \mu \mathrm{M} / \mathrm{L}\end{array}$ & $\begin{array}{l}\text { STHMFP, } \\
\text { in } \mathrm{mM} / \mathrm{M}\end{array}$ & $\begin{array}{l}\text { OC re- } \\
\text { leased } / g \text { of } \\
\text { rock, in } \mu g\end{array}$ \\
\hline \multicolumn{17}{|c|}{ Unchlorinated } \\
\hline GR03085 & $\mathrm{RH}$ & 14.34 & 37.48 & 0.38 & none & na & 7.51 & 4.98 & nd & nd & nd & nd & nd & nd & nd & 7.01 \\
\hline GR03088 & DB-1 & 14.07 & 37.60 & 0.37 & none & na & 8.39 & 2.67 & nd & nd & nd & nd & nd & nd & nd & 0.99 \\
\hline GR03091 & DB-4 & 15.44 & 37.21 & 0.42 & none & na & 8.79 & 2.69 & nd & nd & nd & nd & nd & nd & nd & 0.94 \\
\hline GR03100 & \multicolumn{2}{|c|}{ water only } & 42.00 & 0.00 & none & na & 8.19 & 2.30 & nd & nd & nd & nd & nd & nd & nd & na \\
\hline GR03101 & \multicolumn{2}{|c|}{ water only } & 42.00 & 0.00 & none & na & 8.14 & 2.29 & na & na & na & na & na & na & na & na \\
\hline GR03102 & \multirow{2}{*}{\multicolumn{2}{|c|}{$\begin{array}{l}\text { water only } \\
\text { water only }\end{array}$}} & 42.00 & 0.00 & none & na & 8.14 & 2.22 & na & na & na & na & na & na & na & na \\
\hline GR03103 & & & 42.00 & 0.00 & none & na & 8.12 & 2.30 & na & na & na & na & na & na & na & na \\
\hline \multicolumn{17}{|c|}{ Chlorinated } \\
\hline GR02983 & $\mathrm{RH}$ & 5.04 & 37.18 & 0.14 & 17.9 & 0.0 & 8.02 & 5.36 & 342 & 27.1 & 1.60 & 0.00 & 371 & 3.04 & 6.82 & 22.57 \\
\hline GR02982 & RH & 5.07 & 36.41 & 0.14 & 18.3 & 0.0 & 7.95 & 5.45 & 344 & 29.8 & 1.95 & 0.05 & 376 & 3.08 & 6.78 & 22.63 \\
\hline GR03071 & $\mathrm{RH}$ & 5.02 & 36.00 & 0.14 & 37.3 & 3.4 & 7.92 & 6.10 & na & na & na & na & na & na & na & na \\
\hline GR03070 & $\mathrm{RH}$ & 5.08 & 35.80 & 0.14 & 37.5 & 4.7 & 8.05 & 6.03 & 612 & 39.9 & 3.18 & 0.15 & 655 & 5.38 & 10.7 & 26.34 \\
\hline GR02984 & $\mathrm{RH}$ & 25.08 & 29.55 & 0.85 & 20.3 & 0.0 & 7.73 & 14.19 & 302 & 31.2 & 2.30 & 0.00 & 335 & 2.73 & 2.31 & 14.01 \\
\hline GR03072 & $\mathrm{RH}$ & 24.77 & 28.15 & 0.88 & 84.8 & 0.0 & 7.75 & 16.69 & 858 & 48.7 & 1.65 & 0.05 & 909 & 7.50 & 5.39 & 16.36 \\
\hline \\
\hline GR02985 & DB-1 & 5.11 & 36.77 & 0.14 & 18.1 & 0.0 & 8.61 & 4.12 & 184.1 & 23.7 & 2.17 & 0.02 & 210 & 1.70 & 4.95 & 13.10 \\
\hline GR03076 & DB-1 & 5.14 & 36.38 & 0.14 & 36.9 & 5.4 & 8.38 & 3.10 & 366 & 34.3 & 2.25 & 0.30 & 403 & 3.29 & 12.7 & 5.66 \\
\hline GR03077 & DB-1 & 5.05 & 35.66 & 0.14 & 37.7 & 5.9 & 8.30 & 3.03 & 311 & 30.4 & 2.05 & 0.03 & 343 & 2.80 & 11.1 & 5.15 \\
\hline GR02986 & DB-1 & 5.11 & 36.00 & 0.14 & 18.5 & 0.0 & 8.47 & 4.50 & 215 & 24.1 & 2.07 & 0.02 & 241 & 1.96 & 5.23 & 15.49 \\
\hline GR03078 & DB-1 & 10.66 & 33.30 & 0.32 & 71.7 & 6.1 & 8.28 & 5.19 & 599 & 19.9 & 0.80 & 0.00 & 620 & 5.14 & 11.9 & 9.02 \\
\hline GR02987 & DB-1 & 25.19 & 28.33 & 0.89 & 21.2 & 0.0 & 9.00 & 10.31 & 112.1 & 14.6 & 1.15 & 0.00 & 127.8 & 1.03 & 1.20 & 9.01 \\
\hline GR02989 & DB-4 & 5.04 & 36.65 & 0.14 & 18.2 & 2.3 & 8.23 & 3.23 & 357 & 28.2 & 1.85 & 0.00 & 387 & 3.17 & 11.8 & 6.76 \\
\hline GR02988 & DB-4 & 5.06 & 35.91 & 0.14 & 18.6 & 2.6 & 8.39 & 3.39 & 329 & 25.6 & 1.60 & 0.00 & 356 & 2.92 & 10.4 & 7.73 \\
\hline GR03082 & DB-4 & 23.04 & 28.56 & 0.81 & 83.6 & 20.5 & 8.67 & 4.40 & 806 & 36.8 & 2.75 & 0.15 & 846 & 6.99 & 19.1 & 2.61 \\
\hline GR02990 & DB-4 & 25.05 & 28.78 & 0.87 & 20.9 & 0.3 & 8.93 & 7.65 & 317 & 24.6 & 1.75 & 0.05 & 343 & 2.81 & 4.41 & 6.15 \\
\hline & & & & & & & & & & & & & & & & \\
\hline GR02978 & \multicolumn{2}{|c|}{ water only } & 42.00 & 0.00 & 17.5 & 7.9 & 7.78 & 2.45 & na & na & na & na & na & na & na & na \\
\hline GR02979 & \multicolumn{2}{|c|}{ water only } & 42.00 & 0.00 & 17.5 & 7.9 & 8.28 & 2.39 & 300 & 29.0 & 2.13 & 0.02 & 331 & 2.70 & 13.6 & na \\
\hline GR02980 & \multicolumn{2}{|c|}{ water only } & 42.00 & 0.00 & 17.5 & 7.6 & 8.09 & 2.50 & 322 & 31.2 & 2.32 & 0.02 & 355 & 2.90 & 13.9 & na \\
\hline GR02981 & \multicolumn{2}{|c|}{ water only } & 42.00 & 0.00 & 17.5 & 7.8 & 8.11 & 2.49 & 332 & 29.1 & 2.00 & 0.00 & 363 & 2.97 & 14.3 & na \\
\hline
\end{tabular}


Since 1879, the U.S. Geological Survey has been providing maps, reports, and information to help others who manage, develop, and protect our Nation's water, energy, mineral, land, and biological resources. We help find natural resources, and we supply scientific understanding needed to help minimize or mitigate the effects of natural hazards and the environmental damage caused by human activities. The results of our efforts touch the daily lives of almost everyone. 